\title{
Where have all the nomads gone? Fifty years of statistical and demographic invisibilities of African mobile pastoralists
}

\author{
Sara Randall
}

\begin{abstract}
There is considerable interest in the numbers and population dynamics of mobile African pastoralists alongside a recognition that they are probably undercounted or excluded from many data sources because of the difficulties in enumerating mobile individuals. In the Sustainable Development Goals where it is anticipated that everyone will be counted and their characteristics measured, it is important to develop appropriate strategies for including mobile pastoralists. I document the extent to which mobile African pastoralists have been invisible in the demographic record in the last half century and analyse the diverse pathways by which these invisibilities have been brought about in census and survey data collection exercises in different countries.

A careful review of available documentation for censuses and Demographic and Health Surveys for the band of countries from Mauritania across to Kenya reveals heterogeneous patterns of pastoral nomad statistical invisibility with different forms and intensities according to national and socio-political context. Whereas there was substantial statistical invisibility of mobile pastoralists in the 1980s and 1990s in both data sources, deliberate exclusion has been much reduced in recent years, although there remain issues of clarity and definition.

Although the availability of demographic and statistical data on mobile pastoralists is improving, it is impossible to document with any accuracy any transformations in the numbers of these populations over the last half century. Considerable work on developing appropriate categories and definitions needs to be undertaken if statistics on the characteristics of mobile pastoralists are to be appropriately represented in the Sustainable Development Goals.
\end{abstract}

Keywords: Demographic data; Census; DHS surveys; Pastoralists; Nomads; Africa; SDGs; Indicators; Mobility; Definitions; Population; Mauritania; Mali; Niger; Chad; Kenya; Ethiopia; Tanzania

\section{Introduction}

The Sustainable Development Goals (SDGs) and the earlier Millennium Development Goals (MDGs) both have, as their ultimate goal, the improvement of the human lot at a global level. A key change in the SDGs is the emphasis on inclusion, on counting everyone and on disaggregation (United Nations Secretary General (UNSG) 2014), so that populations which might have previously been excluded, or hidden, become revealed and their situation and progress monitored. Professional groups such as demographers have already identified some issues with this approach (IUSSP 2015), noting the difficulties of disaggregation for demographic indicators which require substantial population sizes in order to identify significant trends and changes.

Correspondence: s.randall@ucl.ac.uk

University College London, London, UK
There are a number of challenges with this 'data revolution' encompassing 'measurable targets and technically rigorous indicators' (United Nations Secretary General (UNSG) 2014: p. 28), one of which is the assumption that sustainable development can best be captured through quantitative indicators and that if the goals represented by these indicators are achieved, progress has necessarily been made. A broad social science literature challenges the perceived objectivity of indicators and suggests that, once an indicator is defined, then both value and validity rapidly becomes undermined because human ingenuity finds new ways of manipulating and controlling the data which constitute the indicator (Davis et al. 2012; Espeland and Sauder 2007; Espeland and Stevens 2014; Merry 2011). Furthermore, despite the admirable goal of inclusivity in the SDGs, there is 
likely to remain a number of populations whose lives, livelihoods and well-being are resistant to the dominant paradigm of quantification and who themselves resist this external control. Through the lens of demographic data, I examine the multiple statistical invisibilities of one such population, African mobile pastoralists, over the last half century. I analyse the range of different forces which contribute to either statistical invisibility or visibility, in order to reflect on the merits, the feasibility and the challenges of the UNSG's aims of counting everyone.

This article aims to document the extent to which mobile African pastoralists have been invisible in the demographic record in the half century since most African countries achieved independence. I examine the diverse pathways by which these invisibilities have been brought about through separate data collection exercises in different countries. Simultaneously, I reflect on the pressures leading to heterogeneous patterns of pastoral nomad invisibility with different forms and intensities according to national and socio-political context.

These goals lead me to consider a number of different bodies of literature around the nature of quantification, indicators, government statistics, power and governmentality (Foucault 2003; Scott 1998) and the light such analyses can throw on different dimensions of nomadic pastoralist statistical invisibility. The literature around pastoral production in arid and semi-arid environments is an important backdrop to understanding the different tensions around the counting and classifications of nomadic pastoralists, especially recent transformations in understanding the role of mobility in successful pastoral exploitation of arid lands. These tensions intersect with the methodological challenges of adapting demographic methods of census and survey inquiry which are, with few exceptions, predicated upon an attachment of human groups to particular geographic spaces through their dwellings. To make things more complicated, the mobility of many pastoralist populations' dwellings is accompanied by a flexibility of the domestic group which is required for adequate, and more often optimal, management of livestock in arid and semi-arid lands.

\section{Pastoral production and mobile pastoralists}

In the huge swathe of arid and semi-arid lands from Mauritania and Senegal in West Africa across to Somalia and parts of Ethiopia, Kenya and Tanzania in East Africa, patchy seasonal rainfall encompasses considerable temporal and spatial variability, with extensive livestock production involving considerable mobility of both livestock and humans being the most productive use of this unpredictable environment (Behnke et al. 1993; Scoones 1994; Homewood 2008; Behnke and Muthari 2011). There is mounting evidence that mobile pastoralists' ability to manage risk and uncertainty through movement may well be a good model for other populations in the context of climate change (Dyer 2013; de Jode 2010). Alongside mobile pastoralism, rainfed agriculture is practised in areas with higher rainfall, and traditional small-scale irrigated and flood-retreat agriculture is also viable in some areas often in favoured dry season pastures. The development of large-scale mechanised irrigation schemes along river courses, some more successful than others, has often impacted negatively on extensive pastoral production by capturing the key resources of grazing and water (Galaty 2014; Fratkin 2014; Catley et al. 2013).

The main characteristic of pastoralism impacting on statistical visibility is the mobility required by effective dryland pastoral production (Bonnet and Bertrand 2014; de Jode 2010; Homewood 2008; Kratli et al. 2014). In the colonial era, considerable proportions of the arid lands' populations were mobile pastoralists and a nomadic lifestyle was widespread; controlling and managing this mobility was often seen as a major challenge by colonial regimes, and in British East Africa, many dry season pastures with substantial agricultural potential were annexed by colonial farmers (Spear and Waller 1993; Hughes 2006; Lane 1996). Diverse ethnic and linguistically defined populations practise extensive pastoralism with various degrees of mobility; they demonstrate great heterogeneity in social organisation and relationships with each other and with other, more sedentary populations. There has always been considerable flexibility about the coexistence of pastoralism with other economic activities such as agriculture, trade, mining and seasonal labour to urban areas. Individuals, families and entire populations have moved in and out of mobile livestock keeping in times of drought or disease (Spear and Waller 1993; Bonfiglioli 1990; Little and Leslie 1999; Brainard 1991; Fratkin and Roth 2005; Toupet 1977).

What exactly makes a pastoralist? Using an economist's perspective, Swift (1988) defined pastoralists as 'households or populations where more than $50 \%$ household income/consumption is derived from livestock or livestock-related activities, either as a result of sales of livestock products or of direct consumption'. Such a definition begs the question of how to classify impoverished pastoralist households who have lost most of their livestock but who aspire to being pastoralists, and furthermore, it is not a practical approach to collecting data on pastoralists because the data are needed before the population can be identified. A more anthropological approach espoused by Galaty (2015) considers a whole 'pastoral continuum' across different ecosystems, with different degrees of mobility, agriculture, subsistence or market involvement. Both Swift and Galaty's approaches highlight the difficulties of isolating pastoralists as an unambiguous population category. In both West and East Africa, across time and space, there are sedentary groups whose 
household economy is dominated by livestock keeping and mobile populations whose livelihoods include activities other than pastoralism. Economic diversification is a key element of most pastoralist livelihoods at the family, camp, village or clan level. Key economic and cultural aims are usually oriented around pastoralism, but other economic activities are often essential complements to the livestock economy and these may impact on degrees of mobility and sedentism over time, over space and within families and households.

In terms of statistical invisibility, however, the problem is not the production system per se or the degree of actual economic engagement with livestock raising. From the demographic perspective, the difficult issue with respect to data is not the fact that these are pastoralist areas but that extensive pastoralism generally means mobility. There is no inherent barrier to collecting demographic data on pastoralists, and this is done effectively in Southern African pastoral populations and in Mongolia, as well as for sedentary agro-pastoral populations worldwide including the countries considered here; problems arise when the pastoralists are mobile and because the diversity of the mobility - transhumance of herders with animals, whole population mobility with herds or partial household mobility or separation because of the needs of the livestock - precludes standardised solutions. The demographic invisibility is not that of pastoralists but that of mobile pastoralists.

Should we therefore use the term nomad rather than mobile pastoralist? For Dyer (2013), researching education, the term 'nomad' is 'analytically unhelpful' because it focuses attention on the lifestyle of the humans rather than on mobility because of livestock requirements. Once people cease to depend on livestock, either through choice or through necessity, they usually cease to be mobile - exceptions being those who provide essential specialist services to mobile pastoralists such as Tuareg blacksmiths who generally transhume with the rest of the population. In contrast, East African blacksmiths are usually sedentary because of their equipment and the resources they need to access. Although Dyer eschews the term nomad, the concept is both useful and pertinent in examining the demographic and statistical invisibility of mobile pastoralists. Furthermore, the term nomade is an important classification in francophone Sahelian countries and use of the term has a direct bearing on statistical invisibility. In other contexts, there may just be linguistic substitution: the 2007 Ethiopian census report states that 'Pastoralists are people who are wandering from place to place in search of grass and water for their animals' (Ethiopia Central Statistical Agency 2010: p. 5). The 1994 Ethiopian census used an identical definition but used 'nomads' instead of pastoralists, highlighting the elision between the categories in that country. An advantage of the term 'nomad' is that it encompasses all those who move regularly as part of their production system; pastoralists, fishers, hunter gatherers and other mobile groups such as gypsy and traveller populations and all of whom tend to be statistically invisible. 'Nomad' will be used here when that term is used in the demographic documentation and literature.

\section{Issues around pastoralists in statistical data Mobility}

In demographic data collection, it is accepted that mobile populations and individuals are poorly represented, whether in rich, more developed, populations or in the global South. Censuses are known to undercount the homeless and migrants, especially undocumented migrants and the highly mobile, although other sub-groups are also difficult to enumerate (Carr-Hill 2014). When a country is known to have a considerable mobile population, then it might reasonably be expected to adapt census methodologies in order to enumerate as many as possible - and this is indeed the case in most of the countries under review.

However, a number of different nuances around mobility mean that good data collection on mobile populations is not just a matter of finding them. Although mobility makes data collection difficult, it also renders the pastoral economy viable. This may mean that more mobile pastoralists are more economically successful but less likely to be captured in any data collection exercise, although some very rich pastoralists do settle, move into politics and delegate herding to highly mobile contract herders. Possibly, those mobile pastoralists who are enumerated in censuses and surveys are the less economically viable, less mobile and therefore the most visible, generating bias in the perceived economic success of the enumerated population.

Secondly, different pastoral populations manage animal and human mobility in very different ways which frequently involve the splitting up of the domestic group; thus, young adult men may be away for weeks or months with cattle or camels whereas adolescents manage sheep and goats with shorter absences from the homestead (Homewood 2008). In the case of Tanzanian Maasai interviewed in Longido District in 2008, the majority of the cattle were often at cattle camps several kilometres from the homestead and in a different administrative jurisdiction. Such cattle camps may include as semi-permanent residents young men, a younger married couple, teenage boys and young pre-school children, whilst the household head and the rest of the domestic group are in a village: both groups of people combined constitute one domestic economic unit sharing a herd and agricultural produce. Census and survey definitions of household then become critical: in most data collection exercises, the household is defined as a co-resident 
domestic group, often reduced to those who eat together (Randall et al. 2011; Randall et al. 2015). Thus, domestic groups where a number of members reside elsewhere to maximise well-being of the family herds will get split up into smaller units than the actual basic socio-economic unit. The enumerated households may appear to be poorer, with fewer assets and inappropriate characteristics of the head of the household and with inaccurate representations of available labour force because of the mobility required to maximise animal production and welfare (Randall and Coast 2015).

A third consequence of mobility for the statistical representation of pastoralists relates to poverty estimates and analyses. Analyses of household-level poverty from nationally representative surveys take one of two approaches: those using household budget surveys with details of income, expenditure and resource flows in and out of the household should, in theory, be able to accommodate pastoral production systems and may even be able to accommodate the split households outlined above. Other surveys do not collect such complex data, and poverty is estimated from asset indices (Sahn and Stifel 2000; Howe et al. 2012) or a combination of assets and housing materials. The requirements of mobility however preclude investment in housing materials included in such indices: the essence of mobile housing is its portability or ease of construction (see https:// www.youtube.com/watch?v=BRvRRxoDggQ), and solid floors, roofs and fixed water supplies are incompatible with this, as are a number of consumer items often included in asset indices such as refrigerators, electric fans and furnishings. Unless livestock are also included in the asset index, then mobile pastoralists, who may have considerable capital, may appear to be very poor. This lack of investment in material goods and housing generates problems in Tanzania and Uganda where such attitudes are seen as being counter to the general ideology of development, although pastoralists are very willing to invest in modern technology that is compatible with and facilitates their livestock-based mobility - things like mobile phones, vaccines and motorbikes. Often, mobility is not recognised by governments as generating a viable production system but is perceived to be an archaic and slightly shameful form of traditional behaviour that should be stopped as soon as possible to facilitate real 'development' (Morton 2010).

\section{Categories and classifications}

A considerable literature explores the history of census taking and the far-reaching implications of the categories and classifications used in censuses (Hacking 1990; Porter 1995; Schor 2009; Szreter et al. 2004). It is beyond the scope of this paper to review this literature in detail, but it is important to note the impact of census classifications on the visibility or invisibility of mobile pastoral populations. The nature of the census exercise means that the complexity of human life has to be simplified and census questions generally force enumerators or the coders of census data to categorise people in ways defined by the census takers' priorities and preoccupations. Subsequent to the census, these categories may take on a life of their own and create boundaries and divisions where previously there was fluidity and flexibility. The Indian caste system is often cited as one situation where the census takers created a system of classification which then reverberated back into numerous dimensions of public and private life, constructing who people were, their relationships to others and, in some cases, what they could do (Legg 2014). The census classification of East African populations into tribes had a similar effect (Spear and Waller 1993) creating distinctions with repercussions for land rights and residence and political representation, power and conflict today, especially in Kenya. Tanzania's socialist regime rejected tribal classifications as divisive and undermining Tanzanian nation building, and no data are collected in Tanzanian censuses and surveys on ethnicity, language or religion. Both the presence of tribal classifications in Kenya and their absence in Tanzania have ramifications for trying to situate mobile pastoralists.

A number of censuses, mainly in francophone countries, but also in Sudan and Ethiopia, have a category 'nomad', reflecting a lifestyle rather than a dependence on a particular economy. In most cases, this classification is based on the mode of accessing and enumerating the population rather than a classification developed out of fitting answers to a specific set of questions into a definition. Elsewhere like Kenya, rather than there being a category into which (some) mobile pastoralists are placed, the opposite is true, and they become difficult to identify in census data.

\section{Governmentality}

The census epitomises a nation state's capacity to govern its population coupled with the state's capacity to actually mobilise the skills and organisation to undertake this gargantuan task. Yet, the census is also part of the way, through the categories used, that states simplify data on complex realities and reduce groups of people, such as nomads, to a homogenous category about which gross, and often unfounded, generalisations are made (Scott 1998). Histories of census taking emphasise the important symbolic status of this data collection exercise, and although some argue that the census has been superseded by much more efficient registration systems in many richer, more statistically developed, states (Coleman 2012), in less developed countries with substantially incomplete civil registration, the census continues to pay a key data role. In the light of the data demands for the SDGs, the 
census is likely to increase in importance over the next 30 years (IUSSP 2015). In the new world order of the SDGs, Foucault's governmentality takes on a new dimension (Foucault 2003): the statistics will be at a global scale, and it is the world community who should govern and monitor the well-being of the global poor to improve their lot. The nation state remains responsible for collecting much of the data, but the international community has an enhanced role in facilitating and policing that collection, through providing finance, support and training to statistical offices.

For poor countries with inadequate infrastructure and high levels of illiteracy, conducting a census is a great challenge; where a considerable proportion of the population is mobile, the challenges are even greater. Documentation of early post-colonial censuses demonstrates the huge effort put into achieving a good census (Randall et al. 2015), in particular, the primary requirement of counting of each individual once and once only. This demonstrated to the United Nations that the country was capable of doing this, despite the challenges, and therefore was a fully participating member of the UN community with the rights and responsibilities (including census taking) that this entailed. Documentation for early censuses in the semi-arid countries considered here gives long and detailed explanations of preparations for collecting data on mobile populations and the different ways this was approached, in order to maximise complete enumeration. This serves both to demonstrate that the mobile populations, despite being difficult to control in a number of ways and often politically marginalised, are nevertheless members of the nation state and potentially governable but also that the nation itself is part of a wider global governance. It should not be forgotten that most African countries in the 1960s to 1980s saw themselves as underpopulated and wanted to claim as many people as possible to demonstrate their power.

Under-enumeration of mobile peoples in censuses and other data-gathering exercises is not just an issue of difficulties in finding them. Mobility may often be part of a deliberate strategy to remain invisible in relation to the state. Although this is particularly the case for people such as illegal migrants, many minority and marginalised populations are justifiably wary of the power of the state; human rights abuses have, at times, been founded on statistical and census data (Selzer and Anderson 2001). Refusing to respond to the census may be a way of exercising resistance as practised by some First Nations populations in Canada (Guimond et al. 2009). Furthermore, census-type exercises undertaken by colonial administrators in Africa were largely about identifying those who should pay taxes, along with numbers and names of children who could be forcibly taken to school and young men for forced labour. Colonial archives detailing the administrative trips to undertake tax censuses of Tuareg, Maure and Peul mobile pastoralists in Mali commonly describe administrators' perceptions of the devious ways used by nomads to disappear over the dune when the administrators arrive and French administrators' perpetual suspicions that both people and livestock had been concealed (Randall 2009). Colonial and post-colonial administration policies have often been counter to the perceived interests of mobile pastoral populations including sedentarisation, forced enrolment in schools, land alienation, inhibition of movement and imposition of barriers and borders. In most countries, except Mauritania and Somalia, pastoralist populations are minorities and rarely have much political power compared to the power held by those from populations and ethnic groups whose dominant production system was sedentary agriculture: those in power, along with actual legislation, usually prioritise dimensions of sedentary lifestyles (Fratkin 2014). Furthermore, many pastoral zones are areas of considerable local and international conflict: Mali and Niger with Tuareg uprisings and Islamist takeover, Chad, Darfur in Sudan, perpetual conflict in South Sudan, Karamoja in Uganda and the numerous conflicts between pastoral groups in northern Kenya including the Somali population. Ethiopia's pastoral zones are also subject to conflict. Apart from the difficulties of data collection in conflict zones should be added the fear, often justifiable, of providing information which could be misused in the future.

On top of the desire for invisibility by certain populations at certain times and the practical difficulties of enumerating mobile populations, there is also the changing political context; for diverse reasons, there may be pressure for the census results to suppress the numbers of different sub-populations. In many countries, like the USA where it is written into the constitution, the census is the basis for the determination of political representation and this has become more frequent in recent decentralisation in Africa. This may offer a counterweight to previous desires for invisibility by minority groups and lead to considerable pressure for everyone to be counted or even for overrepresentation with movements towards corruption or fraud. Here again, the mobility of pastoralists means potential for nationally split populations to cross international boundaries in order to be strategically censused elsewhere - and there are claims by some that this happened in the Kenya 2008 census (Jubat 2011; Mayoyo 2011; Oparanya 2010).

\section{Visibility of pastoral nomads in national censuses}

Available census data suggest a decline in the proportions of nomads (assumed to be mobile pastoralists) in African nations in the last 40 years towards the total disappearance of this lifestyle (Figure 1). Figure 1 uses the data on those classified as 'nomads', a category easily 


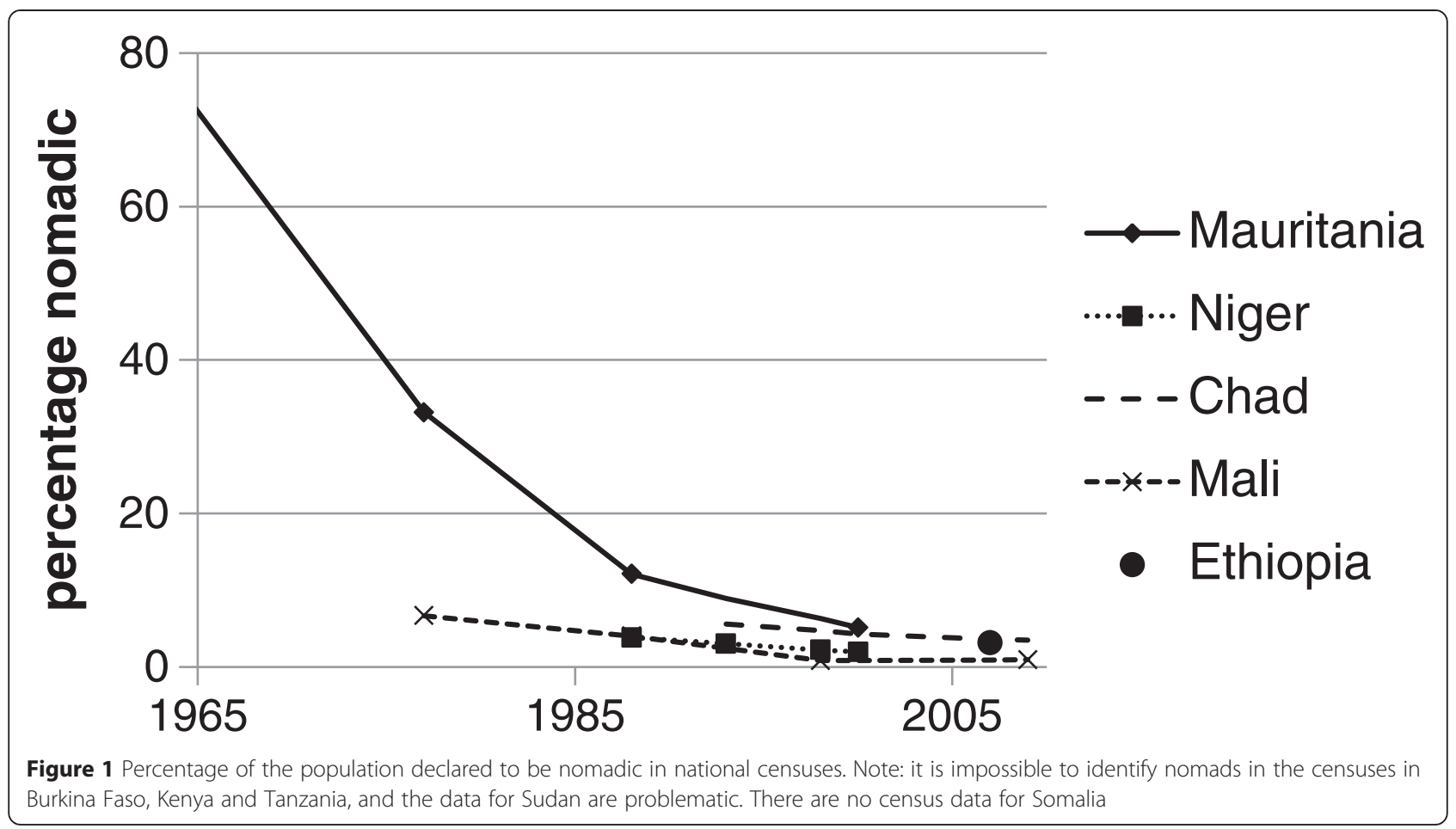

identifiable in these censuses. It is not, by any means, a count of pastoralists in these countries - who, were they countable, would constitute a far greater proportion of the population. Data availability and the definitional issues outlined above mean that counting those who depend wholly or partly on pastoralism is almost impossible. It is however the mobile pastoralists, the nomads, who are most likely to be statistically invisible. The extent to which mobile pastoralists are enumerated in censuses and are subsequently visible in the data depends on a number of factors which include the practical efforts made to identify, locate and persuade them to participate, the different ways in which they are enumerated, the classifications of populations used in different nation states, along with quite fundamental dimensions of a census such as whether it prioritises de facto or de jure enumeration.

Although one difficulty in censusing nomads is the practical issue of their mobility and finding them, exacerbated by the time lag between cartography preparations and actual data collection, for national administrations, there is another, seemingly more fundamental, issue about 'where they should belong', that is, which geographic and administrative jurisdiction they should be associated with. A key problem highlighted in census documentation relates to geographic 'belonging' and the spatial dimensions of census and surveys. There is an underlying methodological assumption that individuals should be associated with a geographic place, and a house or physical structure there.
Concerns about the geographical space and therefore administrative unit to which mobile peoples should be attributed are more acute in francophone than anglophone countries. Following the practices of the colonial power, francophone countries use a de jure approach, counting people in their 'usual' residence, responding to the question of 'who normally lives here?' whether at the household level or aggregating upwards into the population belonging to a specific administrative unit. Anglophone country censuses tend to be quite strictly de facto focusing on where people are on census night. The conceptual difficulties posed by a de jure approach can be seen in the 1975 census report from Upper Volta (now Burkina Faso), a country with a small mobile pastoral population in the north Sahel province.

The case of the nomadic populations would have required a different method of investigation which was not based on the notion of residence. After the 1973 drought many nomadic families tended to sedentarise; we have thus treated the camps as simple villages whose inhabitants are recorded as being present or absent residents. The ill-adapted definition introduces some imprecision in the enumeration of the populations, especially in the Sahel department. Furthermore between nomadic and sedentary there exists a whole range of intermediary states whose boundaries are rarely clear. In this case, the application of precise definitions would not have been sufficient to 
improve the accuracy of the data. (République de Haute Volta 1978: p. 41 author translation). ${ }^{1}$

In Burkina Faso, therefore, mobile pastoralists were included in the census (to the extent that they were found), but they cannot be identified through any particular code or variable. They are just treated like anyone else. The lack of a specific strategy to find them probably means that they were under-enumerated.

Below, I present profiles of different national approaches to enumerating mobile pastoralists in censuses in order to demonstrate the heterogeneity over time and over space of their representation.

\section{Mali}

In Mali, this issue of the administrative unit to which mobile pastoralists 'belong' was largely resolved back in the colonial period and the legacy continues to the present day. The colonial tax regime for pastoralists (called nomades) was different to that for sedentary cultivators, and the unit of taxation for nomades was the 'fraction', an administrative unit based nominally around lineages although often modified. Thus, in the colonial era, the term nomade became shorthand for a tax code and provides an excellent example of Hacking's (1990) dynamic nominalism: in the 1980s, I often heard educated Tuareg civil servants or pharmacists referred to as nomade despite living in very sedentary urban villas. Nomade had, for many Malians, ceased to describe with a way of life and was more associated with ethnicity, rendering it difficult to interpret the Malian census documentation.

All four Malian censuses (1976, 1987, 1998, 2009) classify households as nomad or sedentary with a box ( 1 = sédentaire, 2 = nomade ) to be completed by the enumerator on the front of the census form; this box does not record a response to a question to individuals. In the first three censuses, no instructions in the enumerator's manuals (République du Mali 1976, 1987, 1998) explain what criteria constitute nomade (mobile housing? movement in the last year? a member of a fraction rather than a village?) or sédentaire. Malian census reports do, however, provide a very detailed explanation of how the nomadic populations were informed about the census and how it was actually undertaken. The most detailed report, for 1976 (République du Mali 1980), describes numerous meetings with nomad chiefs, maps of transhumance routes and major camps, and there was a major information programme. Specific nomad enumerators who spoke relevant languages were recruited. According to one 1976 enumerator I interviewed, in his region near Gao there was a camp of enumerators and each day, they were given a list of nomad camps to visit by car or camel. Once in the camp, they went from tent to tent enumerating, just like enumerators going from house to house in sedentary zones. Fraction was recorded and the census report provided age-sex distributions by fraction within each administrative cercle; so, the nomadic population was treated in the same way as a farming village, except that all the members of one fraction enumerated in a cercle would be grouped together in the tabulations. It seems (although was never specified) that the code nomade on the front of the questionnaire denoted the way in which the population was accessed and whether it was by one of these mobile teams of nomade enumerators.

In 1987 and 1998, Malian census reports' descriptions of preliminary work undertaken on nomadic populations are less detailed (République du Mali 1990, 2001). For these censuses, the nomad populations were summoned to points de regroupement. According to a current census office employee (personal communication), it was 'forced regrouping' although it is hard to envisage how this could have been enforced. It is not clear whether people were expected to move there with their entire household, but given the practical problems that would pose, one assumes not. The onus is put on the respondent to turn up to be counted, rather than the enumerator visiting the household. In a politically and economically marginalised population already wary of government activity, one can imagine quite considerable under-enumeration with considerable numbers of people unable to turn up for a variety of reasons including herding demands. Furthermore, by 1987, some formerly nomadic Tuareg had started to sedentarise and construct mud-brick houses. It is possible that these people, although no longer nomadic, were classified as nomad because their houses would not have been recognised administratively as parts of villages and they would have reported as part of a fraction, in which case the classification of nomade does not necessarily reflect lifestyle. It is also a household-level classification, not individual. Thus, in 1998, when considerable numbers of repatriated Tuareg refugees were in sedentary repatriated communities with a range of housing types including tents, shelters and mud brick, all the members of such households would be classified as sedentary even if some young men were highly mobile with the livestock (Randall and Giuffrida 2006).

The placement of the classification box on the outside of the census questionnaire and the absence of definition and explanation in the census enumerator's manuals, along with information in the subsequent Demographic and Health Survey (DHS) report that nomad enumeration areas were not included in the sampling frame (Ballo et al. 2002: p. 301), suggest that 'nomad' was a characteristic of 'how' the household was enumerated. However, enumerators also appear to have used their own initiative to classify households as nomadic: the 1987 census data files sorted by enumeration district 
include districts with both nomadic and sedentary households: on the Dogon plateau, where mobile Peul herders spend the dry season with their animals grazing the field stubble, there are indeed Dogon-speaking agricultural sedentary households interspersed with Peulspeaking, nomad households whose main economic activity is herding. ${ }^{2}$ With no definition of nomad household and no instructions about how to treat them, it was apparently left up to enumerators to decide how these households would be recorded. This probably generated rather inconsistent practices.

The 2009 Malian census changed direction towards greater clarity: instructions about nomads appear in the enumerator's manual as does a definition of mobile housing (République du Mali 2008). Unlike earlier censuses, there was no forced assembly of nomads; instead, census agents went out to find pastoralists around the water holes where they spend the hot season. Extra resources and vehicles were made available for this. This new approach was justified as necessary in the new Malian democracy. However, a civil servant living in Kidal during the 2009 census who was involved in the recruitment of supplementary interviewers to enumerate nomad camps told me that many nomadic pastoralists refused to be enumerated, saying that they bought their food, sold their animals and accessed services like health care from Algeria and thus, they did not see why they should be in the Malian census (personal communication Ag Ahmed).

In terms of completeness of enumeration and visibility of nomads in censuses, Mali has made a considerable effort, even though there was probably under-enumeration in each census because of practical difficulties and suspicion of government data collection by a marginalised minority, who in 1998, had only just returned from years in refugee camps in neighbouring countries after persecution by the military and militias in Mali. Visibility is also an issue in the publication of results: in 1976, many tables in the report were broken down by nomade/sédentaire. In 1987 and 1998, there were far fewer tables, largely limited to the age-sex distributions. This itself sends a message about government attitudes to their mobile populations. It is however possible to generate a 30-year trend of the nomadic population in Mali even if we suspect that there may be considerable undercounting especially in 1987 and 1998 (Figure 1).

\section{Niger}

Like Mali, Niger has also had four censuses, although detailed results for 2012 are not yet available (as of March 2015). Like Mali, the population is classified into nomade and sédentaire. Unlike Mali, the census series is truncated and Niger, like a number of other countries, typifies one way nomads have been rendered invisible. In the first Niger census in 1977, households were classified as either nomadic or sedentary and the questionnaire included excellent questions which could have thrown considerable light on the forms and distribution of mobile pastoralism in the country. Each household was asked 'does the household move with the animals?' with possible answers being 'the whole household,' 'part of the household' and 'no'. The answers to these questions would have allowed a more detailed analysis of mobile pastoralism both in households classified as nomadic and those as sedentary. However, the data on the nomadic population were never published. The report states

Data collected on households and those for nomads do not appear in the various presentations of the results. They included some inadequacies as a consequence of the quality of the cartographic carving up undertaken before the count (République du Niger 1985: avant-propos) $)^{3}$

Another source told me that the actual problem was not the cartography but the data on nomads were suppressed for political reasons. Nevertheless, the report goes on to say how all the published tables will be the basis of population data informing all future development interventions. This suggests that the nomadic population and their characteristics will have been ignored in those development interventions. They became totally invisible in the data.

In the subsequent two censuses, data on mode de vie de ménage - classified as nomade or sédentaire, were collected (see Figure 1). Whereas the report for 1988 has age-sex tabulations by mode de vie (République du Niger 1992), the preliminary report for 2001 (République du Niger 2007a) does not mention nomads at all. Another census report on the website which reports on women states that one of the goals of the 2001 census was to document 'the process of sedentarisation of the nomads ${ }^{4}$ (République du Niger 2007b: p. 18). Thus, in Niger, data on the nomadic population are collected, albeit probably under-enumerated, but the results remain fairly invisible.

\section{Chad}

Chad's first census was in 1993. I have been unable to find any documentation other than a mention in the report for the second census undertaken in 2009, that nomads formed 7\% of the population in 1993 and this declined to $4 \%$ in 2009 (République du Tchad 2009). The 2009 report provides much more detail on the nomadic population than recent Malian and Nigerien reports, possibly because nomads remain a non-negligible proportion of the population. Nomads in Chad are defined (2009: p. 16) as 'the population who has mobile housing. ${ }^{5}$ As in Burkina Faso, there is considerable debate around where the nomadic population should be 
recorded: the place where they were enumerated or their administrative affiliation. Tables are produced for both, with priority given to the administrative affiliation. The commentary on population dynamics also comments on the nomad population saying the annual intercensal growth rate is $3.6 \%$ (3.5\% without refugees) - a potential doubling of the population in less than 20 years. This very high growth rate is a result of the fertility rate which remains very high but could also be explained in part by a better coverage in the Census. The growth rate of the nomad population is much lower $(0.6 \%)$ and can be explained by sedentarisation linked to several factors such as drought and the subsequent degradation in living conditions. ${ }^{6}$ (République du Tchad 2009: 17). It is interesting that, although the apparent overall high growth rate is attributed to improved census coverage, the low growth rate of the nomadic population is not considered to be, even partially, a function of difficulties in enumerating mobile groups.

\section{Mauritania}

Mauritania's attitudes to and enumeration of nomadic populations differ from everywhere else. In Mauritania, the dominant ethnic group with political power has a nomadic pastoralist tradition and this has resulted in census data collection methods that focused on the quality of data collection on nomads and broke with the traditional census link between place and enumeration to use the tribal social organisation instead. With the help of INSEE (Institut National de la Statistique et des Etudes Economiques) of France, there was a sample census in rural Mauritania in 1964 to 1965 . There is considerable documentary detail about the census methodology built around the tribal structure and lineages, identifying those to interview and then interviewing them and everyone else found in the same place (République Islamique de Mauritanie 1972). It was estimated that $77 \%$ of the population was nomadic (Figure 1). There were extremely clear and coherent definitions of nomad and sedentary, and all tables in the census report were broken down by sedentary/nomad. A further sample census (sample of nomads but complete enumeration for the sedentary) was undertaken in 1976/1977 which used a similar approach based on the tribal structure to identify respondents, whilst retaining interviews at household level (République Islamique de Mauritanie nd_a, nd_b). At this time, the nomadic proportion of the population was estimated to have declined to just over $30 \%$. A number of different theses have studied this process of sedentarisation of the Mauritanian nomadic population and provide extremely well-justified and plausible explanations (Traoré 1984; Toupet
1977). The decline here is not because of invisibility but is a genuine social transformation.

In Mauritania in the 1960s and 1970s, it was possible to use the tribal structure as a way of accessing the nomadic population because of the ethnic homogeneity of the population: such an approach would be impossible in environments with several different pastoral nomad populations each with their own tribal structure, language and organisation, as is the case in Chad, Sudan or Kenya. More recent censuses in Mauritania have abandoned the tribal approach and reverted to conventional methods linking humans with space, through identifying the nomadic population along water courses. It remains the case that nomadic Mauritanians do not perceive themselves to be marginalised or oppressed by the government, which is largely made up of those from the same populations, and thus, there is probably less undercounting than elsewhere. Unfortunately, the preliminary report of the 2013 census on the statistics office website (in Arabic) only presents the results for the sedentary population, ${ }^{7}$,saying that the nomadic results will come later.

\section{Ethiopia}

In Ethiopia, insurgencies and civil wars have made it very difficult to carry out censuses, which makes the question political as well as logistical. This is of course tied up with making pastoralists invisible, since such wars are largely attributed to pastoralists such as the Somali, the Oromo and peoples of the Omo Valley. Until the most recent Ethiopian census in 2007, the representation of mobile pastoralists in Ethiopian censuses has been problematic and somewhat obscure. The first census, in 1984, has five different sorts of household, one of which is 'nomad'; like francophone countries, being nomadic is considered to be a household not an individual characteristic (Central Statistical Authority, Ethiopia 1984). However, the census only covered about $81 \%$ of the total population of the country, and many of the omitted zones were pastoralist regions

The census has not covered low land areas with nomadic population; rural areas of Asseb, Tigray and Eritrea and some of the urban centers in Tigray, Eritrea and other regions. The population that had not been covered in the census was estimated to be $8,115,904$ in 1984 and this accounted for $19 \%$ population (Central Statistical Authority 1991: p. 2)

Considerable effort was spent in estimating the total omitted population, although in terms of their socioeconomic characteristics, the report states (p. 6)

and anyway there is hardly any difference in the population in the areas covered by the census and the 
population in the areas not covered by the census. Consequently the report presents values obtained from the census as representing the national characteristics.

In the case of the nomadic population, this assumption of similarity seems very improbable.

The 1994 Ethiopian census is also problematic with respect to the demographic visibility of pastoralists. The whole country was censused in 1994, including nomadic populations, except the nomadic populations of Afar and Somalie regions - the two regions where the pastoralists dominate; the sedentary and urban populations of these two regions were censused with everyone else. The nomadic populations were to be censused in 1995 to 1996, and there is indirect evidence that this was done from an Italian report (Bielli et al. 2001). Although the regional-level reports indicate that all the results in those two regions collected in 1994 were problematic, and the whole regions were resurveyed in 1996, it has proved totally impossible to find any reports or any numbers of the nomads in these two zones. The published regional reports only have the data collected in 1994, which exclude these nomad populations. Even the Integrated Public Use Microdata Series (IPUMS) database in Minnesota has been unable to identify the data from this nomad data collection exercise (Robert McCaa personal communication).

The 2007 Ethiopian census was universal apart from a very few administrative districts. Over 2,500,000 nomads (now called pastoralists) were recorded in pastoralist households, across all the regions (Ethiopia Central Statistical Agency 2010: pp. 8 to 20). Outside the two main pastoral zones (Somali and Affar [sic]), the numbers and proportion of the population recorded as nomadic increased from 126,715 to 202,908 , an increase from $0.26 \%$ of the population to $0.3 \%$ (data provided by Eshetu Gurmu). It is unclear whether this is because of better enumeration of pastoralists, greater willingness to be enumerated or taking up of a mobile pastoralist lifestyle. Given the Ethiopian government policy towards pastoral zones, it seems unlikely to be the latter.

The 2011 Ethiopian DHS states that 'unlike the first census the second [1994] and third censuses [2007] covered the entire population' (Central Statistical Agency [Ethiopia] and ICF International 2012:3). It is not clear whether this is true or not given the impossibility of finding any reports or evidence of the numbers of nomads enumerated in Afar and Somali regions.

\section{Kenya}

Of all the countries with considerable mobile pastoral populations, Kenya has the best census series (with 5 censuses undertaken every 10 years since 1969). In recent years, with the creation of an arid lands Ministry and pressure from a number of INGOs like Oxfam, there has been considerable effort to both support pastoralists and also to generate good data on the pastoralist populations. However, unlike all the countries considered above, Kenyan census data do not permit the identification of mobile pastoralists separately. Data are collected on and classified by ethnicity, itself the subject of considerable academic debate (Spear and Waller 1993). This means that it is possible to understand the evolution of numbers of different pastoral ethnic groups (Turkana, Maasai, Somali, Gabbra, etc.), but these numbers are not disaggregated by lifestyle or mobility, and thus, the numbers of people who remain mobile, who are sedentarised or who have left pastoralism altogether as urban migrants or educated civil servants cannot be separated out. There are many long-term detailed studies of pastoral populations in Kenya, in Turkana (Little and Leslie 1999) and around Marsabit (Fratkin and Roth 2005) and different research projects with Maasai, all of which demonstrate the major transformations which are occurring in these populations, but cannot provide data on the national scale of those who remain mobile pastoralists.

Thus, the data on Kenya's mobile pastoralist population are probably the best, but the numbers and the evolution of the mobile pastoralist population cannot be evaluated. No questions on the census questionnaire (Republic of Kenya 2010) allow mobility to be evaluated. In the 2009 census, the enumeration of pastoralist populations was highlighted as problematic in a number of districts which appeared to have experienced unrealistic population growth since the 1999 census. The government wanted to re-run the census in these areas, but there was considerable opposition to this idea. There appear to be a number of dimensions to the problems: a major drought over the preceding few years had led to considerable genuine population movement of pastoralists in search of pastures. Conflict led to people crossing the borders from Somalia into Kenya. The census of 2009 was the basis for developing electoral constituencies, and there may have been greater willingness of minority populations to be counted in 2009 compared to 1999 because there was some benefit to being administratively visible. All these contributed to apparently unrealistic natural population growth rates. According to some newspaper reports (Mayoyo 2011; Jubat 2011), there was also evidence that cross-border populations exploited their mobility to move into Kenya for the census (de facto) for a variety of reasons. The irony is that mobility will have facilitated all of these strategies, yet there is no way of actually identifying who is mobile. Yet, by including questions on livestock ownership for the first time, the 2009 census has allowed a complete revaluation (upwards) of the contribution of pastoralism to the Kenyan economy (Behnke and Muthari 2011). 


\section{Tanzania}

Pastoralists (and mobile hunter gatherers) in Tanzania are statistically invisible in several ways. The absence of ethnic classifiers in census and survey data is a major way of rendering invisible communities that are largely (although not exclusively) defined by pastoralism in a country where there is a strong political bias towards agriculture. Ethnic labels would be good proxies for livelihoods in geographic areas where diverse production systems (agriculture, pastoralism, fishing and/or hunter gathering are practised) and their absence limit the uses of available data.

For the censuses from 1978 until 2002, Tanzania's approach to mobile pastoralists seems to differ from most other countries. Not only did it render many of them statistically invisible, the documentation around this invisibility is itself difficult to penetrate. In Tanzanian censuses, there was a category of people called 'the migratory population'. According to the methodology report for the 2002 census (p. 28), there were three types of enumeration area: i) normal enumeration areas (EAs) composed of private households; ii) special category EAs composed of collective households like hotels, hospitals, etc.; and iii) special category EAs capturing the migratory population settlements such as temporary camps of nomadic pastoralists, fishermen, honey collectors, etc. Later in this document (p. 52), the migratory population is defined as 'people who have no permanent living residence. They usually move from one living place to another. The reason for this could be that they are looking for new fishing areas, grazing ground etc. Before enumeration the DCEOs contacted their local leaders so as to make special arrangements on how to locate and enumerate such a population. All persons belonging to this category were enumerated where they spent the census night' (United Republic of Tanzania: Central Census Office 2003). The recommendations in the same report (p. 44) suggests that in the future, the 'special category population i.e. fishing camps, mining camps, nomadic populations etc. should be included in the sample design' and this was done for the 2012 census (United Republic of Tanzania 2013). Thus, a number of mobile, and probably not so mobile, pastoralists were almost totally invisible in Tanzanian censuses from 1968 to 2002. Age, sex and marital status data for this 'migratory population' were collected, and they are included in the published tables which use these variables, although not disaggregated except for the village population listings. Otherwise though, no data are available on the migratory population. Although at national level, this will have a negligible impact on any indicators, at a disaggregated level, the invisibility is more marked (see Table 1) with the socio-economic characteristics of some administrative areas effectively missing or seriously underrepresented by most census data.
Table 1 Percentage migratory for selected subdivisions within Arusha province: Tanzanian census 2002

\begin{tabular}{lll}
\hline Administrative district & Population 2002 census & \% migratory \\
\hline Arusha province & $1,288,088$ & 1.54 \\
Ngorongoro District & 109,516 & 15.3 \\
Nainokanoka ward & 15,562 & 22.8 \\
Malambo ward & 9,614 & 67.5 \\
Sale ward & 2,902 & 100 \\
\hline
\end{tabular}

Source: Population tables at village and ward levels provided by NBS

Furthermore, the heterogeneity of the migratory population (including fishermen, honey gatherers, mining communities and mobile pastoralists) means that little socio-economic information can be assumed. The agesex structure of the 'migratory population' demonstrates that this population is not just constituted of young herders: it includes children and the old (Figure 2).

The classification of mobile (or even not so mobile) pastoralists in Tanzanian censuses highlights the Tanzanian government's attitude towards them: their 'special' enumeration areas differ from 'normal' enumeration areas. They are grouped with, but slightly separate from institutional or collective populations and the homeless, but as special EAs, they could never be selected to receive the 'long questionnaire' which collects socio-economic, housing and living standards data. Not only does this mean that their characteristics were inevitably missing from all censuses but also that their (special) enumeration areas could not be selected for the national sampling frame and thus for all subsequent national data collection exercises.

The criteria for classifying communities as migratory are unclear; from the names of the migratory populations in the village listings in the census results, some certainly include communities with solid, stable and relatively immobile traditional housing. One might hypothesise that the official Tanzanian disapproval of pastoralist populations who engage in some mobility and their value systems contributed towards a classification which minimised data collection on them and thus their representation in official statistics, other than as numbers of people by age and sex.

The changes in the Tanzanian census to include the mobile pastoralist populations in the main census questionnaires and the inclusion of questions on livestock ownership in the 2012 render this recent census a much improved tool for understanding the characteristics of the pastoralist population.

\section{General issues around census data collection on mobile pastoralists}

In terms of the visibility of enumerated mobile pastoralists across Africa, there has been a marked improvement 


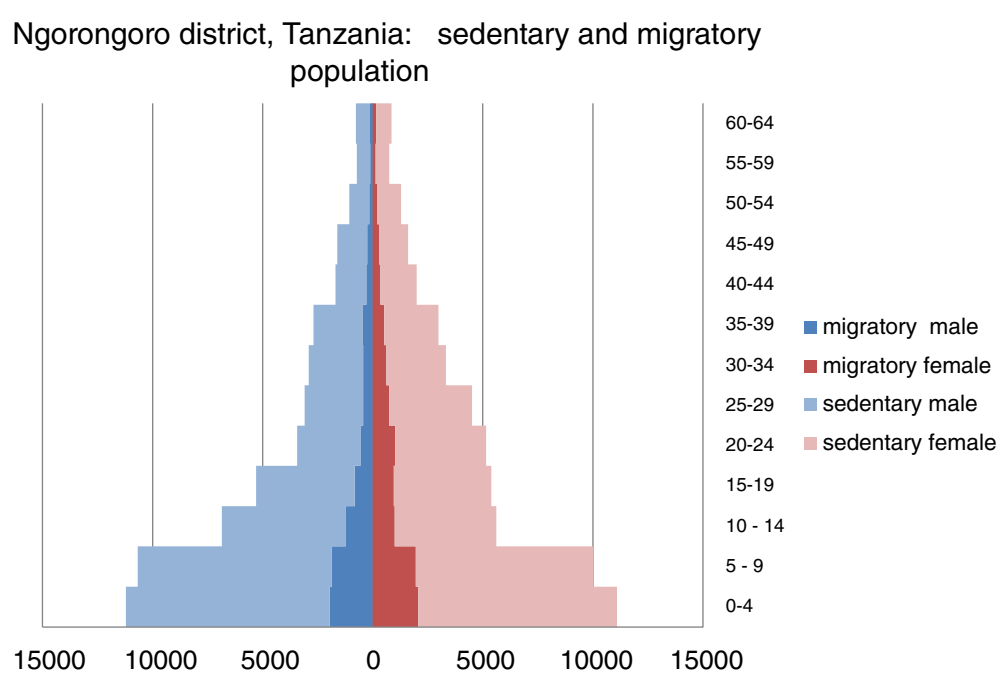

Figure 2 Age-sex distribution of Ngorongoro sedentary and migratory population: 2002 census, Tanzania

in the recent round of censuses since 2010. This does not mean that the issue of the inevitable mobility-related under-enumeration has been solved and it should always be borne in mind. Ethiopia has undertaken its first complete enumeration of settled and mobile populations and the numbers, and some characteristics of pastoralists can be identified. Tanzania has included all of its population, and a full questionnaire is used for all. Mali has ceased to order pastoralists to congregate in certain areas to be counted. Mobile populations or nomads can be identified in the censuses in most francophone countries, and socio-economic data are available for them, although it is rarely specified what particular characteristics led them to be classified as nomadic; however, it is not possible to identify them easily in Kenya, Tanzania and Burkina Faso. On the other hand, serious doubts have been raised about the validity of the high numbers of nomads/pastoralists enumerated in Sudan (Darfur Relief and Documentation Centre 2010) and in pastoral zones in Kenya (Oparanya 2010).

It is difficult to assess the degree of under-enumeration of mobile populations in censuses. In most countries, the documentation suggests that considerable effort has been expended on enumerating them and making practical and conceptual adaptations to their mobility to include as many as possible. This is being achieved under very challenging conditions: huge and sparsely populated areas with few roads, small and mobile communities whose members are very likely to be illiterate, conflict zones, and a sense of marginalisation from the state which continues to be important even if decentralisation and a greater awareness of and potential participation in democratic processes may be giving local populations more incentive to allow themselves to be counted. This detailed review suggests that, for the countries covered here, the situation is better than that outlined by Carr-Hill (2013) and recent improvements suggest that there is some hope for the denominators required by the SDGs.

\section{Household surveys}

Censuses are not the major source of data for many indicators on topics such as mortality, fertility, access to health services and family planning, and there is evidence that not only are mobile pastoralists excluded more systematically from household surveys than from censuses but also, using evidence from Kenya, that pastoral populations are very different from the rest of the country. In terms of population weight, they may be a very small percentage (see Figure 1) although, given under-enumeration, probably $10 \%$ to $40 \%$ higher than recorded in censuses. This low proportion of the population means, as highlighted in many survey reports, that there would be little or no change in national results if they were included or excluded from the data. However, comparing their characteristics with sedentary populations shows that, in terms of many of the indicators used to measure development, well-being and welfare, ${ }^{8}$ they could be classified as seriously disadvantaged.

There are two key relationships between mobile pastoralists, the census and sample surveys: first, the census is usually the source for the national sampling frame, and second, the national sampling frame may be adjusted or used selectively for a specific survey. If mobile pastoralists are under-enumerated in the census, then the enumeration areas (EAs) in which they live will be less likely to be selected for the national sampling frame. Furthermore, if the EAs used for mobile pastoralists were enumerated using a different methodology and have a different classification, then it is very easy to exclude 
them altogether from the sampling frame of any particular survey (see Table 2).

I focus on the DHS survey series below to illustrate the exclusion of mobile pastoralists from household surveys. There are a number of reasons for this: operational since 1985, this data source, of which there are four or five in many countries, is very important for a number of health indicators. Because the data are collected in a standardised format, are open access and are very well documented, they are widely used for national studies and international comparative work over space and over time. They are a major source of data for a large number of PhDs worldwide and used by many researchers to examine numerous issues by using the data in creative ways that go well beyond key indicators. Most DHS survey reports start by stating that 'this is a nationally representative survey' unless certain geographic areas have been excluded (as in the first three Kenya DHS and the Mali 2012 DHS, in which case there is a map in the introduction indicating which areas are excluded). Furthermore, the majority of analyses, published articles and $\mathrm{PhD}$ theses which use DHS data start with a statement like 'DHS surveys are all nationally representative' (e.g. Sahn and Stifel 2000), and this is often an important justification for using this data source.

\section{Pastoralist population characteristics in Kenya from the Demographic and Health Surveys}

In Kenya, a number of pastoral districts were excluded from the first three DHS surveys (1989, 1993, 1998): Turkana, Samburu, Marsabit and Isiolo districts were not sampled at all, neither was the whole of North-East province. All were sampled in the 2003 and subsequent surveys. Because DHS surveys are only representative at provincial level, one cannot easily assess the impact of excluding Turkana, Samburu, Marsabit and Isiolo, but the characteristics of North-East province can be compared with those of other provinces in 2003. The differences are striking (Figure 3).

Using these simple indicators, Figure 3 demonstrates that in terms of education or utilisation of different forms of health care, North-East province is totally different from the rest of Kenya, and in terms of typical indicators of socio-economic development, it is seriously disadvantaged. On the other hand, HIV prevalence was $0 \%$ in North-East province but higher elsewhere. Although there are a large number of mobile pastoralists in North-East province, these data do not just cover mobile pastoral populations: they also include urban and sedentarised populations (both of whom might be expected to be more schooled and have increased use of services compared to mobile groups). The data do indicate how excluding mobile pastoralists from national surveys may give a distorted picture for indicators disaggregated down to a local level.

Such a comparison of the included and the excluded is possible for Kenya because exclusions were at provincial level and because DHS coverage is now national. Similar comparisons for other countries are usually impossible because the exclusions are categories of people rather than geographical areas or, if they are geographical areas, they are not entire provinces.

In most African countries with a sizeable population of pastoral nomads, the nomadic populations are excluded from the DHS sampling frames although frequently, this point is made in a footnote or an appendix and after the introduction has stated that it was nationally representative

As can be seen from Table 2, where geographic areas are excluded from a DHS, this is made very clear at the beginning of the main body of the report. However, a number of surveys are either silent on how they dealt with mobile populations (Burkina Faso, Tanzania, Uganda) or mention the exclusion of nomadic EAs from the sampling frame in Appendix A (Ethiopia, Mali, Mauritania, Niger, Sudan). Thus, not only are mobile pastoralists invisible in the data, to a considerable extent, this lack of visibility extends to the documentation of the exclusions.

As with the census however, the DHS along with the National Statistics Offices with whom they collaborate have made efforts over recent years to be more inclusive in their representation of pastoral peoples. This is most marked in Kenya but is also the case in Niger, Ethiopia and Uganda. Given that the sampling frames for the DHS usually depend on the census, there remains a trickle-down effect of any census under-enumeration into surveys. Furthermore, there is rarely any explanation of practical measures used to identify mobile households. Thus, although the pastoral zones are included, it remains quite possible that households which are listed exclude the more mobile just because local authorities and chiefs are not aware of them passing through or do not consider that they belong under their jurisdiction. Mobile households which are listed in the cartography phase may be less likely to be found again at the interview stage - as in Chad 1996-7 (Ouagadijo et al. 1998). As an example, the proportion of households completed in the 2011 Ethiopian DHS was lower in Affar and Somali regions than in any other region except Gambela (Central Statistical Agency [Ethiopia] and ICF International 2012: p. 280).

\section{Discussion}

African mobile pastoralists are not only invisible in a considerable number of statistical sources and indicators, but the nature of their invisibility is often couched in obscurity. Under-enumeration is almost guaranteed even when 
Table 2 Coverage of nomadic populations in (Demographic and Health Surveys (DHS)

\begin{tabular}{|c|c|c|c|c|}
\hline Country & $\begin{array}{l}\text { Years of } \\
\text { DHS }\end{array}$ & Sampling frame & Mention of pastoral nomads & $\begin{array}{l}\text { Place in report where } \\
\text { nomads were mentioned }\end{array}$ \\
\hline \multirow[t]{4}{*}{ Burkina Faso } & 1993 & \multirow{4}{*}{$\begin{array}{l}\text { Preceding } \\
\text { census }\end{array}$} & \multirow[t]{4}{*}{ No mention in the main text or appendices } & \\
\hline & 1998-99 & & & \\
\hline & 2003 & & & \\
\hline & 2010 & & & \\
\hline \multirow[t]{2}{*}{ Chad } & 1996-97 & 1993 census & $\begin{array}{l}\text { - } 3 \text { nomad clusters were mapped in cartography phase but could } \\
\text { not be located for survey. 5-6\% population in } 1993 \text { census } \\
\text { was nomadic. }\end{array}$ & p. 11 \\
\hline & 2004 & 1993 census & - No mention of nomads & Appendix \\
\hline \multirow[t]{5}{*}{ Ethiopia } & 2001 & 1994 census & $\begin{array}{l}\text { - In Affar region, only } 3 / 5 \text { zones were covered and in Somalie region, } \\
\text { only } 3 / 9 \text { zones. Justified because the population is small and exclusion } \\
\text { unlikely to affect national and urban-rural estimates. Sample excluded } \\
\text { the nomadic population. }\end{array}$ & Footnote to Appendix A \\
\hline & 2005 & 1994 census & $\begin{array}{l}\text { - There may be some bias in the representativeness of the regional } \\
\text { estimates for both the Somali and Affar regions, primarily because } \\
\text { the census frame excluded some areas in these regions that had } \\
\text { a predominantly nomadic population.' }\end{array}$ & p. 7 \\
\hline & \multirow[t]{3}{*}{2011} & \multirow[t]{3}{*}{2007 census } & $\begin{array}{l}\text { - In the Somali region, in } 18 \text { of the } 65 \text { selected EAs listed, households } \\
\text { were not interviewed for various reasons, such as drought and security } \\
\text { problems, and } 10 \text { of the } 65 \text { selected EAs were not listed due to security } \\
\text { reasons. Therefore, the data for Somali may not be totally representative } \\
\text { of the region as a whole. However, national-level estimates are not } \\
\text { affected, as the percentage of the population in the EAs not covered } \\
\text { in the Somali region is proportionally very small. }\end{array}$ & p. 7 \\
\hline & & & $\begin{array}{l}\text { - Due to security concerns in the Somali region, in the beginning, } \\
\text { it was decided that } 2011 \text { EDHS would be conducted only in } 3 \text { of } 9 \\
\text { zones in the Somali region: Shinile, Jijiga and Liben, same as in the } \\
2000 \text { and } 2005 \text { EDHS. However, a later decision was made to include } \\
3 \text { other zones: Afder, Gode and Warder. }\end{array}$ & Appendix A: p. 275 \\
\hline & & & $\begin{array}{l}\text { - Also oversampling in Affar and Somali in order to have robust } \\
\text { regional estimates }\end{array}$ & Appendix A: p. 277 \\
\hline \multirow[t]{6}{*}{ Kenya } & 1989 & \multirow[t]{6}{*}{ NASSEP } & $\begin{array}{l}\text { - Excludes North-East province and } 4 \text { northern districts which together account } \\
\text { for only about } 5 \% \text { of Kenya's population. }\end{array}$ & p. 4 and map \\
\hline & 1993 & & - As for 1989 - but excluded areas less than $4 \%$ of Kenya's population & p. 4 and map \\
\hline & 1998 & & - As for 1993 & p. 6 and map \\
\hline & \multirow[t]{2}{*}{2003} & & \multirow{2}{*}{$\begin{array}{l}\text { - Covered entire country including northern districts excluded from } \\
\text { previous surveys. Smaller number of households in NE province } \\
\text { because of difficulties in travelling and interviewing in sparsely } \\
\text { populated and largely nomadic population. }\end{array}$} & p. 6 \\
\hline & & & & p. 7 \\
\hline & $2008-9$ & & $\begin{array}{l}\text { - Whole country including arid and semi-arid. Fewer households in } \\
\text { NE province }\end{array}$ & pp. 7 to 8 \\
\hline \multirow[t]{5}{*}{ Mali } & 1987 & $? ?$ & $\begin{array}{l}\text { - Rural stratum only representative at } 90 \% \text { to } 95 \% \text { because excluded } \\
\text { all rural populations in Tombouctou and Gao regions and all } \\
\text { nomadic population }\end{array}$ & p. 4 \\
\hline & $1995-6$ & 1987 census? & $\begin{array}{l}\text { - Excluded rural populations of Gao, Tombouctou and Kidal } \\
\text { because of } 65 \% \text { national territory and only } 10 \% \text { population. } \\
\text { No mention of nomads. }\end{array}$ & Footnote p. 7 \\
\hline & 2001 & 1998 census & - Excluded all nomad EAs as identified in the census & p. 301 Appendix A \\
\hline & 2006 & & - Excluded all nomad EAs & Appendix \\
\hline & 2012-13 & 2009 census & $\begin{array}{l}\text { - Excluded whole of North of country for security reasons. Highlights } \\
\text { that it is not representative and not comparable to previous DHS }\end{array}$ & $\begin{array}{l}\text { Preface and map } \\
\text { and p. } 11 .\end{array}$ \\
\hline Mauritania & $2000-1$ & & Only sedentary population & Appendix A \\
\hline
\end{tabular}


Table 2 Coverage of nomadic populations in (Demographic and Health Surveys (DHS) (Continued)

\begin{tabular}{|c|c|c|c|c|}
\hline \multirow[t]{5}{*}{ Niger } & 1993 & 1988 census & $\begin{array}{l}\text { - Excluded some pastoral zones in the northern desert. Excluded } \\
\text { areas about } 1 / 3 \text { surface area but less than } 1 \% \text { population }\end{array}$ & Appendix A \\
\hline & 1998 & & $\begin{array}{l}\text { - As for } 1993 \text { plus extra zones excluded for security reasons } \\
\text { (mainly in nomad zones). About 4.7\% population not represented. }\end{array}$ & Appendix A \\
\hline & 2006 & 2001 census & - Included most of the nomad zones omitted in previous surveys & Appendix A \\
\hline & \multirow[t]{2}{*}{2012} & \multirow[t]{2}{*}{2001 census } & \multirow{2}{*}{$\begin{array}{l}\text { - Excluded } 3.5 \text { clusters in Agadez because of security. } \\
\text { Included nomadic zones excluded in previous surveys }\end{array}$} & p. 8 \\
\hline & & & & Appendix A \\
\hline Sudan & 1989 & & $\begin{array}{l}\text { - Excluded South Sudan because of insecurity and excluded } \\
\text { the nomadic population of North Sudan }\end{array}$ & Appendix A \\
\hline \multirow[t]{5}{*}{ Tanzania } & $1991-92$ & 1988 census & - No mention of mobile pastoralists but census excluded migratory EAs. & \\
\hline & 1996 & & - Same EAs as in 1991 & \\
\hline & 1999 & & - Same EAs as in 1991 & \\
\hline & $2004-5$ & 2002 census & - No mention of mobile pastoralists but census excluded migratory EAs. & \\
\hline & 2010 & & - As for 2004 to 2005 & \\
\hline \multirow[t]{5}{*}{ Uganda } & 1989 & & $\begin{array}{l}\text { - } 9 \text { districts excluded for security reasons ( } 20 \% \text { of population). } \\
\text { No mention of pastoralists }\end{array}$ & p. 5 \\
\hline & 1996 & & - Because of insecurity, 8 EAs not surveyed & p. 5 \\
\hline & $2000-1$ & & - 4 districts excluded for security reasons. $5 \%$ of total population & p. 4 \\
\hline & 2006 & 2002 census & $\begin{array}{l}\text { - First DHS to cover whole country including Karamoja } \\
\text { (pastoralist) and IDP camps both of which were oversampled }\end{array}$ & p. 40 \\
\hline & 2011 & 2002 census & $\begin{array}{l}\text { - Covered whole country. Karamoja had the lowest proportion } \\
\text { of completed selected rural households }\end{array}$ & Appendix A \\
\hline
\end{tabular}

Source: DHS country reports www.dhsprogram.com/publications/

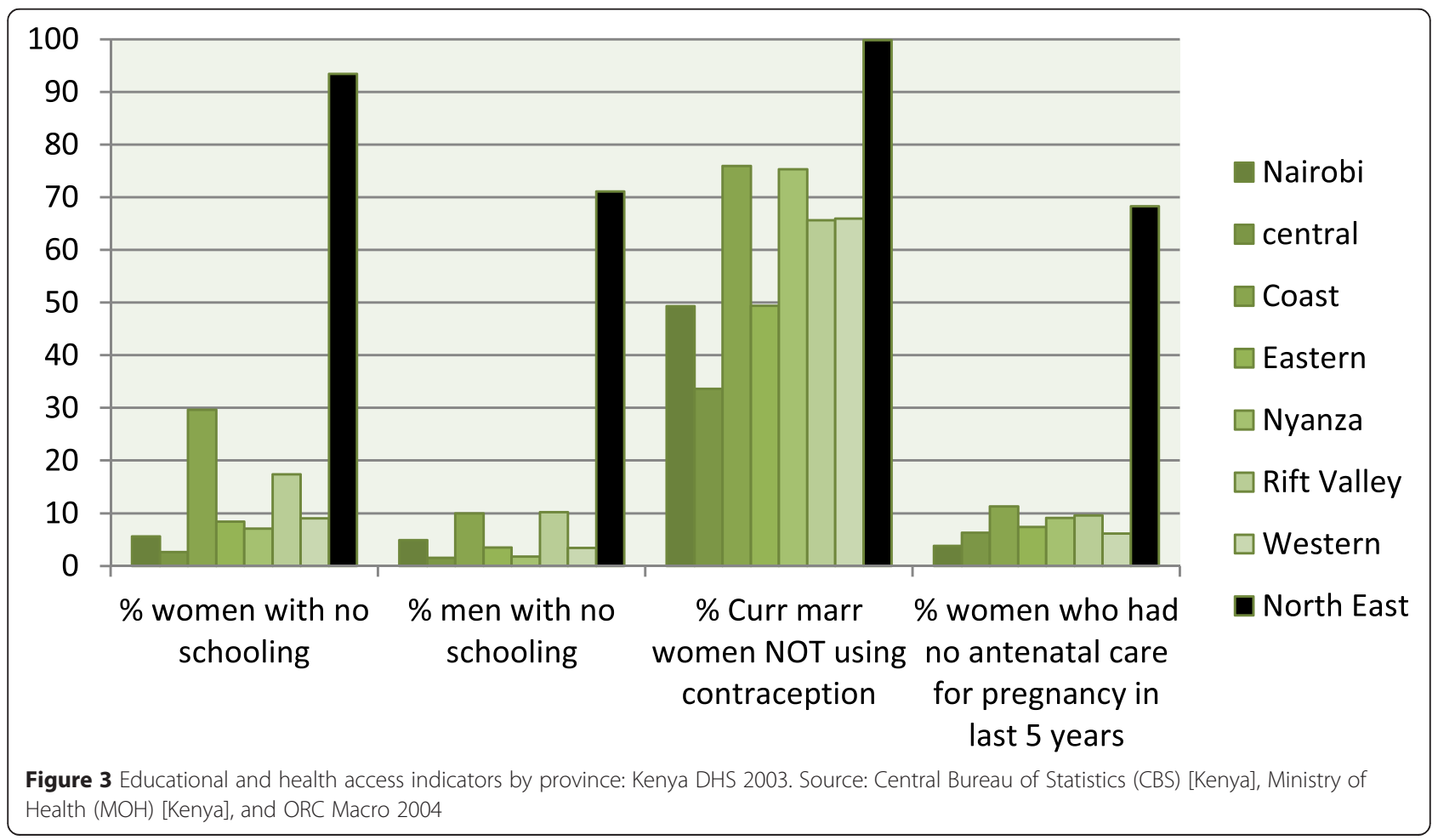


huge efforts are made to include them in the census. This in itself is not surprising. However, where mobile pastoralists are included in the enumeration and are identifiable, the almost total absence of definitions and criteria means that we have little idea what the actual figures might mean. It becomes difficult to know what place on the mobile-sedentary continuum and pastoralist-other economic activities spectrum the households classified as nomad actually lie. Although there is considerable evidence about the problems and repercussions generated by census categories, it is clear from the mobile pastoralist case that an absence of categories with their attendant definitions is even more problematic. It can lead to situations with huge, and largely inexplicable, disparities in numbers as exemplified in the abstract of a recent publication on Mali which states 'In Mali, nomads (Maures, Tuareg and Peulh) constitute about 1.25 million people' (Ag Ahmed 2015: my translation). Yet, the Mali census undertaken in 2009 enumerated 133,084 nomads $^{9}$ - a nearly 10-fold difference. In most countries, there are no clear questions to census respondents which would allow them to classify their lifestyle, and in the only case where simple, appropriate questions were asked, the Niger 1977 census, the data were never published. It seems likely that, in the absence of guidelines and definitions, stereotypes or even personal political agendas held by individual enumerators are likely to influence the way they characterise different households that they encounter.

The absence of categories and definitions itself conveys attitudes towards these mobile populations. Either this absence indicates that the distinction between nomade and sédentaire is so obvious that it needs no further explanation (like male and female) - which is clearly not the case given the wide spectrum of lifestyles, mobile housing and engagement with pastoralism - or it implies that this categorisation does not matter to national priorities.

Furthermore, the nomadic households that are most likely to be captured by censuses are probably not representative of the whole cross section of pastoral society but are more likely to be those close to settlements, those in large groups around substantial water sources and those who are less mobile. They may well have very different socio-economic characteristics to those who are omitted in the data collection exercise.

Whatever the vagaries of census data collection, in most countries, mobile pastoralists are more visible in censuses than in sample surveys where a number of different pathways contribute to their exclusion. This has serious ramifications for pastoralists' representation in the Sustainable Development Goals, where many of the indicators will depend on survey data. This is not the only problem to be confronted. The goal of the SDGs as outlined by the DG (2014 p. 7) '... a data revolution is unfolding, allowing us to see more clearly than ever where we are and where we need to go, and to ensure that everyone is counted.'. In this new era, almost everything is being built on 'measurable targets and technically rigorous indicators' p. 28. The international community is being made more responsible for the poor, but the principal channel of information about this responsibility is through the medium of quantitative data. There is little doubt that, in the majority of countries, mobile pastoralists were excluded from the indicators measuring progress towards the MDGs. The questions then become firstly, whether ways can be found to include them and represent them in the SDGs and secondly, whether they want to be included or whether many would prefer to remain invisible.

A number of different household survey series are used to produce data to inform government policies and development programmes and to generate indicators used for monitoring MDGs and SDGs: Demographic and Health Surveys (DHS), Household Budget Surveys, MICS and Living Standards Measurement Study (LSMS). Here, I focused on the DHS surveys partly because of ease of access to the standardised documentation (itself a reason why this data source is very widely used). In contrast, investigation of the Niger LSMS documentation demonstrated considerable ambiguity about the inclusion of mobile pastoralists. The pastoral zones were certainly included in the data set, but it was unclear whether mobile households were selected from the sampling frame (Republic of Niger 2013).

Disaggregation is one dimension of the SDGs which is a challenge for many indicators (IUSSP 2015). However, it is challenging in a different way for mobile pastoralists: to be workable, disaggregation will often follow administrative boundaries. In the contemporary world, there are few administrative districts that only contain mobile pastoralists - almost all will have small towns, settled populations and inmigrants from elsewhere. Furthermore, mobile pastoralists usually move beyond and over administrative boundaries although most will have an administrative affiliation to a particular geographic area and many censuses do record this. The disaggregation may be no better at portraying the particular needs and characteristics of mobile pastoralists than previous statistical regimes, and the matching of numerators and denominators is likely to be extremely challenging.

So, should there be new ways of conceptualising data on mobile pastoralists and new ways of collecting such data? In some contexts, and for some populations, one could replicate the Mauritanian approach to their sample census in 1964 and 1977 - using the tribal chiefs and the lineage system. This might work for some populations, for example Somali groups, but is unlikely to be viable for most: collecting such data would be hugely 
labour intensive, and in populations where for decades people have left pastoral production because of drought, conflict, schooling and myriad other reasons, such approaches would only capture a particular social subset. However, in contrast to censuses which probably tend to enumerate the least mobile, such approaches might be a good way to capture the most mobile and the most integrated into traditional power structures and social organisation although care would need to be taken to avoid double counting of more sedentary individuals. Innovative ways of collecting demographic data on both mobile herders and their herds have been tested (Jean-Richard et al. 2014) in a feasibility study in Chad using mobile phones and small-scale incentives to report events, which showed that relatively good demographic data could be collected this way, although a number of problems remain to be resolved. Both these approaches are locally targeted - they cannot be replicated on a national scale; they would add to the, already well-developed, collection of local studies on mobile pastoral populations (see Randall 2008 for examples), but they would be impossible to integrate into the national data collection schemes and thus into the pathways to reporting many of the SDG indicators.

Have the numbers of mobile pastoralists decreased over the twentieth century? The (flawed) census data indicate that the proportions of the population engaged in a mobile lifestyle have declined (see Figure 1) and a considerable literature points to the sedentarisation of both the rich (a small minority) and the poor who have lost most/all their livestock and thus no longer need to be mobile. Although there are claims that nomads have lower natural fertility than sedentary populations (Randall 2008), in most contexts, these claims are difficult to substantiate and contemporary evidence indicates that populations in pastoralist zones have higher fertility than those in more settled or more urban areas, a factor primarily related to access to schooling and to health and contraceptive services. Nevertheless, it means that populations of pastoralist origin will often have very high population growth rates, possibly higher than elsewhere in the countries concerned, and therefore, all things being equal, one would expect their proportion to increase, not decrease.

Figure 4 shows the same census data used in Figure 1 but with numbers rather than proportions giving a rather different picture about the dynamics of mobile pastoralism. The lack of time series for Ethiopia precludes a commentary: numbers in Chad and Niger are relatively stable, have declined considerably in Mauritania, and declined in Mali and then picked up again. Over the last 25 years, Mali has, however, experienced a rebellion which caused most pastoralist Tuareg and Maures to flee to Mauritania for several years before repatriation and much sedentarisation in Mali (Randall and Giuffrida 2006). More recently, events in Libya caused many former Malian Tuareg who had moved there to return to Mali. The coup d'état in 2012 and the subsequent chaos and temporary secession of an Islamic State in the north of the country implicated many nomadic Tuareg in diverse ways, and new waves of refugees fled again to neighbouring countries over 2012 to 2014. All these events have influenced the populations of mobile pastoralists, their presence in the country or in refugee camps in neighbouring countries and also their likelihood of responding to any survey or census.

Without going down a crude and inappropriate route of carrying capacity, it is likely that across the whole arid-semi-arid belt, rainfall uncertainty, herd mobility and economic viability, the capacity of the land is limited in its ability to support extensive pastoralism alone. It would be unsurprising if the numbers of nomadic humans that the livestock can support could increase much although diversification into other economic activities and livelihoods can complement pastoralism, most such activities encourage sedentarisation rather than nomadic pastoralism. Rather than looking at the proportions of the population, this approach gives a much more positive perspective on pastoralist population dynamics. However, it does not alter the fact that, apart from the bare (probably underestimated) numbers, these numerically relatively stable populations remain largely invisible in national statistics and international indicators.

In many of the countries which feature in Figure 4 and those which are absent (Kenya, Sudan, Tanzania and Somalia), the appearance/disappearance or visibility and invisibility of mobile populations has political dimensions. These may be related to conflict, power struggles and desires to manipulate population numbers, or movements of persecuted pastoralist populations into refugee camps in neighbouring countries, where, by definition, they are no longer mobile pastoralists, but may also be excluded from census enumerations. These issues do seem to affect mobile pastoralists disproportionately, and one could speculate about why this should be so. The frequency with which mobile pastoralists are blamed in some way for poor data (or inconvenient and unwanted data results) makes them appear like convenient scapegoats because their mobility means that it is usually impossible to verify any claims made. But, there are also political dimensions to the general exclusion of nomadic pastoralists from national data; with the exception of Mauritania, pastoralists with their mobile lifestyle are seen as rather disreputable, certainly uncontrollable, and a blot on a country's international image (Morton 2010). They would be even bigger blot if appropriate data were available because the nature of many of the 


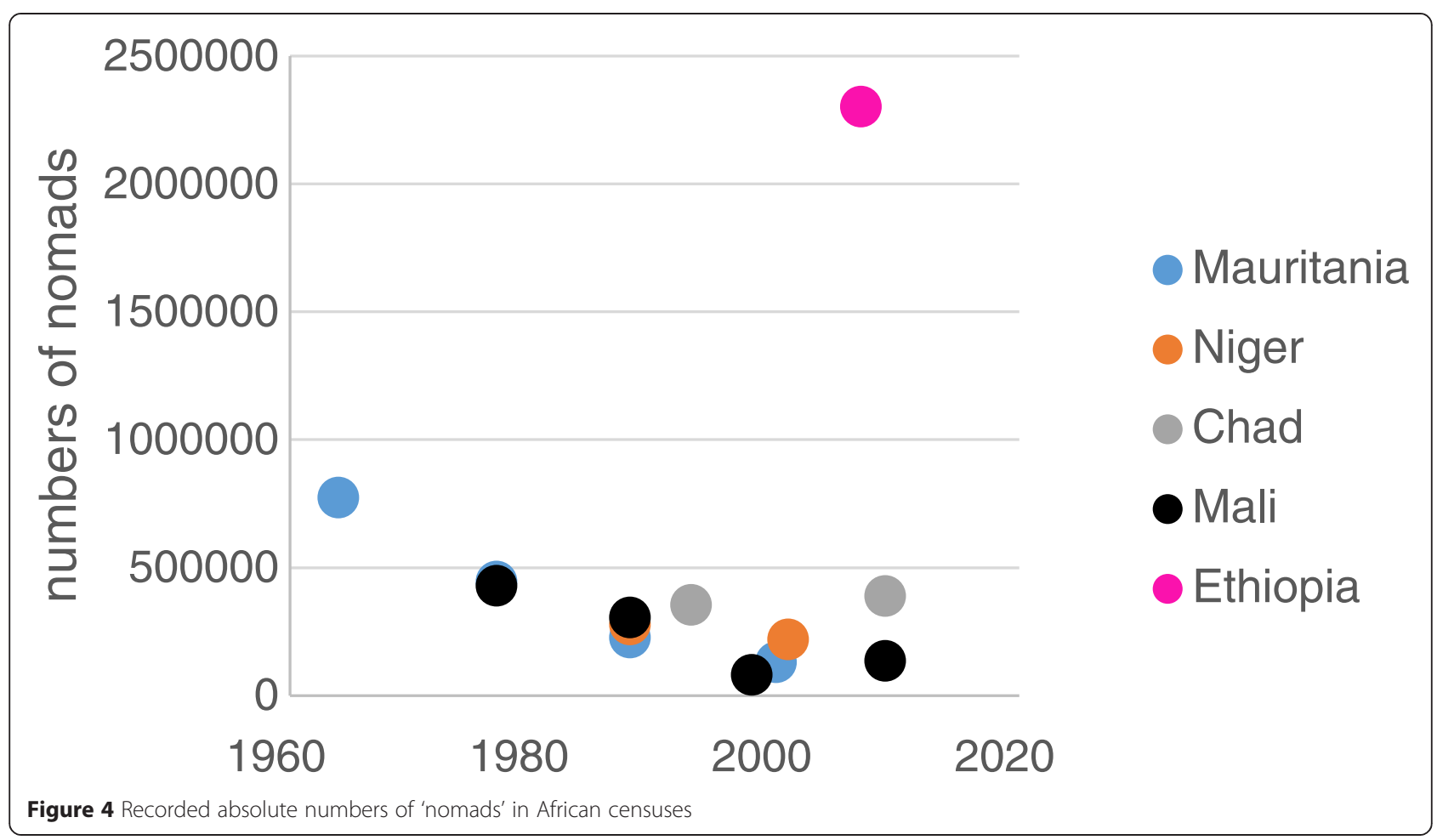

indices measuring 'development' captures aspects of life which may be seen as inappropriate or irrelevant for a mobile lifestyle.

\section{Conclusion}

In documenting the extent to which mobile African pastoralists have been invisible in the demographic record in the past half century, I have shown that the invisibility itself is very heterogeneous and multi-layered. There are data on the numbers of nomads but little more than crude (probably undercounted) numbers of groups of people who are so poorly defined and with such poor meta data that we have little idea of who these groups encompass or any of their defining characteristics. This suggests that, in most of these countries excepting Mauritania, enumerating the nomads was important to demonstrate the full size of the national population, but there was very little interest in terms of really knowing anything about their characteristics. Given that most census reports state that census data are important for planning and development, and that is often the main explicit justification for undertaking this extremely expensive data collection operation, then one can conclude that mobile pastoralists are not, and never were, intended to be a target for focused and well-adapted interventions. Sedentarisation and transforming them into 'proper' citizens is another matter.

A number of different pathways to invisibility have been identified. These include poor definitions and poorly specified instructions to enumerators, forced congregation with the onus to be enumerated placed on the respondent, data collected on far fewer characteristics of individuals and their household, collection of data which are ill adapted to measuring poverty and wealth of mobile pastoralists, categorisations which fail to capture key elements of mobile pastoral well-being and adaptations such as split and flexible households, lack of published tables, inability to identify from the data - and particularly from published tables - the particular characteristics of mobile pastoralists, specific types of enumeration area enabling easy exclusion from sampling frames, deliberate exclusion from most sample surveys, and the temporal disjunction between the cartography and the interviewing phases of a survey meaning that mobile groups are unlikely to be identified in both. These are coupled with a more general spatial and political marginalisation in many countries which means that pastoral nomads are far less likely to be schooled and to have good contact with administrative services, and thus fundamental data, such as age, which are collected, are likely to be less accurate than for other populations.

In DHS surveys where mobile pastoralists are excluded from the sampling frames, there are often statements justifying the exclusion saying it is only $2 / 3 / 4 \%$ of the population and inclusion would make no difference to national indicators'. Although this is true, if those indicators could be disaggregated down to the local population level, the excluded populations would almost certainly 
be extremely different and usually highly disadvantaged compared to the national average. The demand for disaggregation in the SDGs may mean that they can no longer be swept under the carpet.

These countries do not generally want their mobile pastoralists to be totally invisible. A desire to have as complete a census enumeration as possible, both in terms of signalling competence to the outside world and also in terms of having accurate overall population numbers, means that a great effort is made to find and count mobile populations, and in many cases, considerable documentation ensures that the effort made is recognised. However, there is generally insufficient information and data collected to know which individuals, households and populations are genuinely using mobility as an important aspect of their production and the importance of mobility across the country in ensuring a viable and successful extensive pastoralist economy.

Furthermore, the lack of any coherent time series of data mean that we really have little idea of the population dynamics of mobile pastoralism: it is fairly unambiguous that as a family-managed production system, it has largely disappeared in Mauritania although one suspects the mobility of herds and herders remains much higher than that of the general population, but that this is masked by the collected of mobility data at household rather than individual level. Mali too, with four censuses, shows a rapid decline in nomades, but here, the role of conflict which has particularly affected the mobile pastoralist ethnic groups means that the data in recent years are very difficult to interpret. Kenya and Tanzania have time series data, but it is impossible to identify the degree of pastoral-related mobility in the census data. Kenya does have household-level livestock ownership for the 2009 census.

We will never know the absolute numbers of mobile pastoralists for the half century between independence in the early 1960s and 2010 which was probably the time when there was greatest proportional drop-out from this way of life as a result of a combination of a number of interrelated factors: climatic (dry after the relatively wet years of the 1940s and 1950s), political (pressures of sedentarisation, political control of those seen as uncontrolled and at the margins) and socio-economic (pressure from government, NGOs and international development organisations). However, the critical factor now is no longer the population history, although that would have been useful, but whether these populations are doomed to remain invisible in the next phase of the development story: that of the Sustainable Development Goals and the data revolution. If mobile pastoralists are to be represented, then ways need to be found of ensuring they are in the denominators via the censuses, which is not too difficult because the systems to do so are already largely in place and have been refined over 30 years. However, the definitions and the characteristics of mobile populations in different categories in the census need to be much clearer and better documented in order for them to be compatible with other data sets. Most importantly, different ways need to be found of ensuring that mobile pastoralists and other mobile populations are included in other sources of data collection, including household surveys, and not simply excluded because they are difficult to manage. Furthermore, given that it is quite likely that their characteristics and indicators differ considerably from those for other populations, adequate sample sizes are necessary to enable estimates of indicators. If necessary and appropriate, data from neighbouring countries should be pooled. In the case of mobile pastoralists, this often makes sense because ecosystems, ethnic groups and lineages rarely respect international frontiers.

\section{Recommendations}

Sample surveys should make considerable effort to include mobile pastoralists. This means that they need to be included at the cartography and listing stages and decisions need to be made about who is resident. Extra information needs to be obtained to ensure that any mobile pastoralists in an area are known about. Most now have mobile phones, and phone numbers could be a way of ensuring they are included in the survey if the household is selected.

Censuses and surveys need to have better documentation about any extra measures taken to identify mobile pastoralists (or specifically mention the absence of any such measures). Where categories such as 'nomade' are used, there needs to be a definition of the criteria used to define 'nomade'. Instructions to enumerators need to be provided and the criteria for 'nomade' included in the enumerators' manuals.

In order to have a better understanding of the different forms of human mobility associated with pastoralism, the questions, used in Niger 1977, on whether all, part of none of a household moves with livestock would be a simple but effective way of improving understanding about mobility. Inclusion of questions on livestock ownership and numbers (as in the recent Kenyan and Tanzanian censuses) would demonstrate clearly the contribution of pastoralism to the national economy as well as permit sampling of pastoralist populations in surveys.

\section{Endnotes}

1"Le cas des populations nomades aurait necessité une méthode d'investigation différente qui ne soit pas fondée sur la notion de résidence. Apres la sécheresse des années 1970, nombre de familles nomades ont tendance à se 
sédentariser; on a alors consideré les campements comme des simples villages dont les habitants ont été inscrits en tant que résidents présents ou absents. Linadaptation des définitions introduit une imprécision dans le denombrement des populations, tout particulièrement dans le département du Sahel. De plus entre le nomadisme et la sédentarisation il existe de nombreuses situations transitaires dont les limites ne sont pas toujours très strictes. Et, dans ce cas, l'application de definitions particulières n'aurait peut-être pas été suffisant pour améliorer la precision des données." (Haute Volta 1978 census report: p. 41)

${ }^{2}$ Although a close look at the data suggests that there are also a number of misattributed households such as a single Dogon-farming household classified as nomadic amongst other sedentary Dogon households, or vice versa, a single Peul- or Tamasheq-speaking herding household was classified as sedentary amongst a community of otherwise nomadic households.

3"les données collectées relatives aux ménages et celles portant sur les nomades ne figurent pas dans les diverses présentations des résultats. Elles comportent quelques insuffisances du à la qualité des opérations de découpage cartographiques menées avant le dénombrement" (Niger census report 1977: p. 6)

${ }^{4}$ le processus de sedentarisation des nomades

${ }^{5}$ la population qui a un habitat mobile

${ }^{6}$ Le taux annuel moyen d'accroissement intercensitaire est de 3,6\% (3,5\% sans les réfugiés), soit un doublement potentiel de la population en moins de 20 ans. Ce taux très élevé résulterait du niveau de fécondité encore très élevé mais pourrait s'expliquer aussi en partie par une plus grande exhaustivité du dénombrement au RGPH. Le taux d'accroissement de la population nomade est beaucoup plus faible $(0,6 \%)$ et pourrait s'expliquer par la sédentarisation liée à plusieurs facteurs dont la sécheresse et la dégradation des conditions de vie qui s'en est suivie

${ }^{7}$ Thanks to Muhammed Ahmed for the translation.

${ }^{8}$ Which may be rather inappropriate indicators and certainly not necessarily the ones that pastoral populations subscribe to - but that is a different story.

${ }^{9}$ And a total of $1,718,309$ individuals over the age of 3 with Peul, Tamasheq or Maure as their mother tongue.

\section{Competing interests}

The author declares that she has no competing interests.

\footnotetext{
Acknowledgements

Presentations of earlier versions of this paper benefitted from comments from the staff and students at McGill University, Montreal, and from GIERSA in Montreal and Quebec. The paper could not have been written without the availability of the fantastic archive of documentation of old African francophone censuses and surveys help by ODSEF, Université Laval, Quebec (https:// www.odsef.fss.ulaval.ca/) and Richard Marcoux. The IPUMS source documents (https://international.ipums.org/international/enum_materials.shtml) were also invaluable. Thanks to Katherine Homewood, Ernestina Coast and three anonymous reviewers for the comments on earlier versions.
}

Received: 19 June 2015 Accepted: 6 October 2015

Published online: 04 November 2015

\section{References}

Ag Ahmed, MA. 2015. Des agents de santé communautaires pour la promotion de la santé des pasteurs nomades au Mali. Global Health Promotion. doi:10.1177/1757975915573879

Behnke, Roy, and David Muthari. 2011. The contribution of livestock to the Kenya Economy. IGAD LPI Working Paper No. 03-11. Great Wolford: Odessa Centre.

Behnke, Roy, lan Scoones, and Carol Kerven (eds.). 1993. Range ecology at disequilibrium: New models of natural variability and pastoral adaptation in African Savannas. London: Overseas Development Institute.

Bielli, Carla, Berhanu Gezu, Isaias Amare, and Orasi Arianna. 2001. Population growth and environment in Ethiopia. Addis Ababa \& Rome: Central Statistical Authority and Institute for Population Research- National Research Council. http://www.irpps.cnr.it/etiopia/pdf/Population_Growth_and_ Environment.PDF Accessed October 2014.

Bonfiglioli, Angelo Maliki. 1990. Pastoralisme, agropastoralisme et retour: Itinéraires sahéliens. Cahiers des Sciences Humaines 26: 255-266.

Bonnet, Bernard, and Guibert Bertrand. 2014. Stratégies d'adaptation aux vulnérabilités du pastoralisme: Trajectoires de familles de pasteurs (1972-2010). Afrique Contemporaine 2014(1): 37-51.

Brainard, Jean. 1991. Health and development in a rural Kenyan community. New York: Peter Lang.

Carr-Hill, Roy. 2013. Missing millions and measuring development progress. World Development 46: 30-44.

Carr-Hill, Roy. 2014. Measuring development progress in Africa: The denominator problem. Canadian Journal of Development Studies 35: 136-154.

Catley, A, Jeremy Lind, and lan Scoones. 2013. Pastoralism and development in Africa: Dynamic change at the margins. Abingdon and New York: Earthscan.

Coleman, David. 2012. The twilight of the census. Population and Development Review 38(supp): 334-351.

Darfur Relief and Documentation Centre. 2010. 5th population and housing census in Sudan - an incomplete exercise. Geneva: DRDC. http:// southsudaninfo.net/wp-content/uploads/reference_library/reports/ 5th_population_housing_census_sudan.pdf. Accessed 12 March 2015.

Davis, Kevin, Benedict Kingsbury, and Sally Engle Merry. 2012. Indicators as a technology of global governance. Law and Society Review 46: 71-104.

de Jode, Helen. 2010. Modern and mobile: The future of pastoral production in Africa's drylands. London: IIED \& SOS Sahel International.

Demographic and Health Surveys (DHS) http://www.dhsprogram.com/ Accessed 17 June 2015

Dyer, Caroline. 2013. Does mobility have to mean being hard to reach? Mobile pastoralists and education's 'terms of inclusion'. Compare 43: 601-621.

Espeland, Wendy, and Michael Sauder. 2007. Rankings and reactivity: How public measures recreate social worlds. American Journal of Sociology 113: 1-40.

Espeland, Wendy, and Mitchell Stevens. 2014. A sociology of quantification. European Journal of Sociology 49: 401-436.

Foucault, Michel. 2003. Governmentality. In The essential Foucault: Selections from the essential works of Foucault 1954-1984, ed. Rabinow Paul and Rose Nikolas, 229-245. New York: The New Press.

Fratkin, Elliot. 2014. Ethiopia's pastoralist policies: Development, displacement and resettlement. Nomadic Peoples 18: 94-114.

Fratkin, Elliot, and Eric Roth. 2005. As pastoralists settle. New York: Kluwer.

Galaty, John. 2014. 'Unused' land and unfulfilled promises: Justifications for displacing communities in East Africa. Nomadic Peoples 18: 80-93.

Galaty, John. 2015. Pastoralism in anthropology. In International encyclopedia of the social and behavioral sciences, second edition, ed. Wright JamesD. Kidlington, Oxford: Elsevier Ltd.

Guimond, Eric, Norbert Robitaille, and Sacha Senecal. 2009. Les Autochtones du Canada : une population aux multiples definitions. Cahiers québécois de démographie 38(2): 221-251.

Hacking, lan. 1990. The taming of chance. Cambridge: Cambridge University Press.

Homewood, Katherine. 2008. Ecology of African pastoralist societies. Oxford: James Currey.

Howe, LD, B Galobardes, A Matijasevich, D Gordon, D Johnston, O Onwujekwe, R Patel, E Webb, D Lawlor, and JR Hargreaves. 2012. Measuring socio-economic position for epidemiological studies in low- and middle-income countries: a methods of measurement in epidemiology paper. International Journal of Epidemiology 41(3): 871-886. doi:10.1093/ije/dys037. 
Hughes, Lotte. 2006. Moving the Maasai: A colonial misadventure. Basingstoke, UK: Palgrave Macmillan.

IUSSP. 2015. The IUSSP on a data revolution for development. Population and Development Review 41: 172-177.

Jean-Richard, Vreni, Lisa Crump, Doumagoum Moto Daugla, Jan Hattendorf, Esther Schelling, Jakob Zinnstag. 2014. The use of mobile phones for demographic surveillance of mobile pastoralists and their animals in Chad: Proof of principle. Global Health Action 7: 23209. http://dx.doi.org/10.3402/ gha.v7.23209

Jubat, Adow. 2011. Standard digital news: Leaders reject planned census, term it biased.. https://www.standardmedia.co.ke/?articlelD=2000040052\&story_title= Leaders-reject-planned-census,-term-it-biased. Accessed 15 March 2015.

Kratli, Severio, Marie Monimart, Blamah Jalloh, Jeremy Swift, and Ced Hesse. 2014. Accompagner la mobilité pastorale au Tchad: Construction d'un modèle innovant d'intervention pour le développement. Afrique Contemporaine 2014(1): 69-82.

Lane, C. 1996. Pastures Lost: Barabaig economy, resource tenure, and the alienation of their land in Tanzania. Nairobi: Initiatives Publishers.

Legg, Stephen. 2014. Foucault's population geographies: Classifications, biopolitics and governmental spaces. Population Space and Place 11: 137-156.

Little, M, and P Leslie (eds.). 1999. Turkana herders of the dry savanna. Ecology and biobehavioural response of nomads to an uncertain environment. Oxford: Oxford University Press.

Mayoyo, Patrick. 2011. Kenya: Go ahead with repeat census, urge NGOs. The Nation.. http://allafrica.com/stories/201108161302.html Accessed 15 March 2015.

Merry, Sally Engle. 2011. Measuring the world: Indicators, human rights, and global governance. Current Anthropology 52: S83-\$95.

Morton, John. 2010. Why should governmentality matter for the study of pastoral development? Nomadic Peoples 14: 6-30.

Porter, Theodore M. 1995. Trust in numbers: The pursuit of objectivity in science and public life. Princeton: Princeton University Press.

Randall, Sara. 2008. African Pastoralist Demography. Chapter 8 in Ecology of African Pastoralist Societies. (editor) K.Homewood. Oxford: James Currey.

Randall, Sara. 2009. La natalité Touarègue: des représentations coloniales aux réalités post-rébellion. In Mémoires et démographie : Regards croisés au Sud et au Nord, ed. R Marcoux and Dion Jennifer, 253-259.. Collection Cahiers du CIEQ. Quebec: Presses de l'Université Laval.

Randall Sara, and Ernestina Coast. 2015. Poverty in African households: the limits of survey representations. Journal of Development Studies 51(2): 162-177. http://dx.doi.org/10.1080/00220388.2014.968135.

Randall, Sara, and A Giuffrida. 2006. Forced migration, sedentarisation and social change: Malian Kel Tamasheq. In Nomadic Societies in the Middle East and North Africa: Entering the $21^{\mathrm{st}}$ century, ed. Chatty Dawn, 431-462. Leiden: Brill.

Randall, Sara, Ernestina Coast, and Tiziana Leone. 2011. Cultural constructions of a critical demographic concept: The survey household. Population Studies 65(2): 217-229.

Randall Sara, Ernestina Coast, Philippe Antoine, Natacha Compaore, FatouBinetou Dial, Alexandra Fanghanel, et al. 2015. UN census 'households' and local interpretations in Africa since Independence. Sage Open April-June: 1-18. doi:10.1177/2158244015589353

Sahn, D, and D Stifel. 2000. Poverty comparisons over time and across countries in Africa. World Development 28(12): 2123-2155.

Schor, Paul. 2009. Compter et classer. Paris: Histoire des recensements américains EHESS.

Scoones, lan (ed.). 1994. Living with uncertainty: New directions in pastoral development in Africa. London: Intermediate Technology Publications.

Scott, Pete. 1998. Seeing Like a State: How Certain Schemes to Improve the Human Condition Have Failed. New Haven: Yale University Press.

Selzer, William, and Margo Anderson. 2001. The dark side of numbers: The role of population data systems in human rights abuses. Social Research 68: 481-513.

Spear, Thomas, and Richard Waller (eds.). 1993. Being Maasai. London: James Currey.

Swift, Jeremy. 1988. Major issues in pastoral development with special emphasis on selected African countries. Rome: FAO.

Szreter, Simon, Hania Sholkamy, and A Dharmalingam. 2004. Contextualizing categories: Towards a critical reflexive demography. In Categories and contexts: Anthropological and historical studies in critical demography, ed. Szreter Simon, Hania Sholkamy, and A Dharmalingam, 3-32. Oxford: Oxford University Press.

Toupet, Charles. 1977. La sédentarisation des nomades en mauritanie centrale sahelienne. Universite de Paris VII.

Traoré, Sadio. 1984. La sédentarisation et la migration en Mauritanie de 1965 à 1976: Mesure et interprétation. Mémoire à la Faculté des Etudes Supérieurs, University of Montreal.
United Nations Secretary General (UNSG). 2014. The road to dignity by 2030: Ending poverty, transforming all lives and protecting the planet, 34. New York: United Nations. http://www.un.org/ga/search/view_doc.asp?symbol=A/ 69/700\&Lang=E Accessed 14 May 2015.

\section{Government documents produced by Statistical Offices (by country)} Burkina Faso (Haute Volta)

République de Haute Volta. 1978. Recensement Général de la Population 1975: résultats définitifs, volume 1: les données nationales. Ouagadougou: Ministère du Plan et de la Coopération.

\section{Chad}

Ouagadijo, Bandoumai, Kosteingar Nodjimadji, Joel Nodjimbatem Ngoniri, Ningam Ngakoutou, Keumaye lgnégongba, Joel S. Tokindang, Oumdague Kouo, Bernard Barrère, Monique Barrère. 1998 Enquête Démogrpahique et de Santé Tchad 1996-7. Calverton, Maryland USA: Bureau Central du Recensement and Macro International

République du Tchad. 2009. Deuxième Recensement Général de la Population et de l'Habitat (RGPH2 2009): Résultats Globaux. Njamena: Ministère de l'Economie et du Plan.

\section{Ethiopia}

Central Statistical Agency [Ethiopia] and ICF International. 2012. Ethiopia Demographic and Health Survey 2011. Addis Ababa, Ethiopia and Calverton, Maryland, USA: Central Statistical Agency and ICF International.

Central Statistical Authority. 1991. The 1984 Population and Housing Census of Ethiopia: Analytical report at national level. Addis Ababa: Office of the Population and Housing Census Commission.

Central Statistical Authority, Ethiopia. 1984. Census questionnaire, http://catalog.ihsn.org/index.php/catalog/3599 Accessed 15 March 2015

Ethiopia Central Statistical Agency. 2010. Population and Housing Census report - country - 2007. Addis Ababa: Central Statistical Agency. http://www.csa.gov.et/index.php/2013-02-20-14-51-51/2013-04-01-11-53-00/ census-2007 Accessed 15 March 2015.

\section{Kenya}

Central Bureau of Statistics (CBS) [Kenya], Ministry of Health (MOH) [Kenya], and ORC Macro. 2004. Kenya Demographic and Health Survey 2003. Calverton, Maryland: CBS, MOH, and ORC Macro.

Oparanya, Wycliffe Ambetsa. 2010. 2009 Population and Housing Census Results (Kenya). http://www.knbs.or.ke/docs/PresentationbyMinisterforPlanningrevised.pdf Accessed 22 July 2013

Republic of Kenya. 2010. The 2009 Kenya Population and Housing Census, volume 2, population and household distribution by socio-economic characteristics. Nairobi: Kenya National Bureau of Statistics.

\section{Mali}

Ballo, Mamdou Bassery, Seydou Moussa Traoré, Isaka Niambele, Souleymane Ba, Mohamed Ayad, Salif Ndiaye. 2002. Enquête Démographique et de Santé, Mali 2002. Calverton, Maryland, USA: Macro International Inc.

République du Mali. 1976. Manuel de I'agent recenseur. Bamako: Bureau Central de Recensement.

République du Mali. 1980. Recensement Général de la Population, décembre 1976. Tome 1 : série population et socio-démographique. Bamako: Bureau Central de Recensement.

République du Mali. 1987. Manuel de l'agent recenseur. Bamako: Bureau Central de Recensement.

République du Mali. 1990. Recensement Général de la Population, avril 1987. Tome 1 : Population, Economie et Habitat. Bamako: Bureau Central de Recensement.

République du Mali. 1998. Recensement Général de la Population et de l'Habitat: Manuel de I'agent recenseur. Bamako: Bureau Central de Recensement.

République du Mali. 2001. Recensement Général de la Population, avril 1998. Tome 1 : série socio-démographique. Bamako: Bureau Central de Recensement.

République du Mali. 2008. Manuel de l'agent recenseur: quatrième recensement général de la population et de l'habitat 2009. Bamako: Direction Nationale de la Statistique.

\section{Mauritania}

République Islamique de Mauritanie. 1972. Enquête Démographique 1965 Résultats Définitifs. Paris: INSEE.

République Islamique de Mauritanie. nd_a. Recensement Général de la Population 1976: Volume I Résultats Prioritaires Nouakchott: Ministère de l'Economie et des Finances.

République Islamique de Mauritanie. nd_b. Recensement National de la Population 1976: Enquête Nomade Manuel d'Enquête. Nouakchott: 
Ministère de l'Economie et des Finances.

Niger

République du Niger. 1985. Recensement Général de la Population 1977.

Résultats définitifs Rapport d'Analyse. Niamey: Ministère du Plan.

République du Niger. 1992. Recensement Général de la Population 1988. Résultats définitifs, Serie 2, Données de Structure. Niamey: Ministère de l'Economie et des Finances, Bureau Central de Recensement.

République du Niger. 2007a. Rapport provisoire sur les caractéristiques de I'habitat et cadre de vie des populations à partir des données du RGP/H 2001. Niamey: Institut Nationale de la Statistique. http://www.stat-niger.org/ statistique/download.php?lng=fr\&pg=275 Accessed 15 March 2015

République du Niger. 2007b. Situation socio-économique des femmes au Niger. Niamey: Institut Nationale de la Statistique. http://www.stat-niger.org/ statistique/download.php?lng=fr\&pg=279 Accessed 15 March 2015

Republic of Niger. 2013. 2011 National Survey on Household Living Conditions and Agriculture (ECVM/A-2011) Basic Information Document. Niamey: National Institute of Statistics.

\section{Tanzania}

United Republic of Tanzania: Central Census Office. 2003. Methodology Report, vol. 1, 1-99. Dar es Salaam: National Bureau of Statistics.

United Republic of Tanzania. 2013. 2012 Population and Housing census: Vol.2, population distribution by age and sex. 471p. Dar es Salaam: National Bureau of Statistics.

\section{Submit your manuscript to a SpringerOpen ${ }^{\circ}$} journal and benefit from:

- Convenient online submission

- Rigorous peer review

- Immediate publication on acceptance

- Open access: articles freely available online

- High visibility within the field

- Retaining the copyright to your article

Submit your next manuscript at $>$ springeropen.com 